\title{
Hikâye Odaklı Video Oyunlarda Çevirinin Rolü: The Last of Us Video Oyunu Üzerine Bir Değer- lendirme
}

\author{
The Role of Translation in Story Driven Video Games: An Evaluation of The Last of Us
}

\author{
Araştırma/Research
}

\section{Tutku ÖNCÜ YILMAZ* , Emre CANBAZ**}

*istanbul Üniversitesi Sosyal Bilimler Enstitüsü Çeviribilim Doktora Programı Öğrencisi, Araştırma Görevlisi, Yaşar Üniversitesi, İnsan ve Toplum Bilimleri Fakültesi, Mütercim-Tercümanlık, tutku.oncu@gmail.com, ORCID ID: orcid.org/0000-0002-1398-7938

**istanbul Üniversitesi Sosyal Bilimler Enstitüsü Çeviribilim Doktora Programı Öğrencisi, Araştırma Görevlisi, Yaşar Üniversitesi, İnsan ve Toplum Bilimleri Fakültesi, Mütercim-Tercümanlık, emre.canbaz@yasar.edu.tr, ORCID ID: orcid.org/0000-0002-9893-3399

\section{ÖZET}

Günümüzde geniş kitlelerle buluşmayı amaçlayan video oyun şirketleri, farklı ülkelerdeki pazarlarda da varlık göstermekte ve rekabet etmektedir. Bu süreçte, özellikle hikâye odaklı video oyunlarda görsel, işitsel ve dilsel çerçevede sunulması amaçlanan sürükleyici deneyimi farklı kültürlerde de yaşatma gerekliliği ortaya çıkmaktadır. Bu noktada, anlatı dünyasını oluşturmada görsel ve işitsel bağlamın tamamlayıcısı olan dil önemli bir yere sahiptir. Dil verisinin anlatı dünyasını güçlendirecek uygun dinamiklerle işlenmesi, video oyunun yazınsal kalitesini artıııken aynı zamanda şirketlerin satış amacına da hizmet etmektedir. Yapılan çalışmada, özellikle hikâye odaklı video oyunlarda altyazı çevirisinin önemini vurgulamak amaçlanmıştır. Bu doğrultuda, tüm dünyada yüksek satış rakamları yakalayan ve hikâye ve anlatı başta olmak üzere pek çok kategoride ödüle layık görülen The Last of Us adlı video oyunun Türkçe altyazı çevirilerinden seçilen örnekler değerlendirilmiştir. Çeviri eylemi, bu çalışmada yapılacak değerlendirmeye zemin hazırlamak için ekonomik ve yazınsal olmak üzere iki boyutta ele alınmıştır. Ardından, çeviri kararlarını etkilediği düşünülen iç ve dış bağlam üzerinde durulmuştur. İç bağlamda video oyunlardaki metin türleri ve özellikleri, dış bağlamda ise video oyun çevirisine iliş̧in farklı yaklaşımlar ve süreçler ele alınmıştır. Bu doğrultuda, çalışmanın kuramsal çerçevesi görsel-işitsel çeviri ve çeviri sürecini etkileyen normlar ışı̆ıında şekillenmiş̧ir. Seçilen video oyunun Türkçe altyazı çevirisi, betimleyici bir yaklaşımla ve Gideon Toury’nin sorun-çözüm çifti yöntemi kullanılarak incelenmiştir. İnceleme sonucunda, erek metindeki tercihlerin, çevirmen kararları kadar çeviri sürecinden de etkilenebileceği düşünülmektedir. Sonuç olarak, oyundaki metinlerin hikâyeyi oluşturan görsel ve işitsel öğelerin tamamlayıcısı olduğu görülmüştür. Çeviri süreci kapsamında alınan kararların da bu bulguya uyumlu olması önem taşımaktadır. Çalışmada, video oyun çevirisinin oyuncu ve oyun arasındaki iletişimi güçlendirmesi açısından öneminin altı çizilmiştir. Bu süreçte çevirmenlerin iletişim uzmanı rolü ile akademik çeviri eğitiminde kazandırılması hedeflenen 
çeviri edinci gerekliliği de vurgulanmıştır. Böylelikle, bu çalışmanın video oyun çevirisi ve değerlendirmesinin çeviribilim alanındaki görünürlüğüne katkı sağlayacağı düşünülmektedir.

Anahtar Sözcükler: video oyun çevirisi, çeviri değerlendirme, çeviri eleştirisi, video oyun yerelleştirme, lokalizasyon

\section{ABSTRACT}

Video game companies aiming to meet with the masses today also exist and compete in markets in various countries. In this process, especially in story-driven video games, it is necessary to provide the immersive experience which is intended to be presented in the visual, audio and linguistic framework in different cultures. At this point, language, which is a complement to visual and audio context, has an essential place in creating a narrative world. The processing of language data with the appropriate dynamics that will strengthen the fictional world increases the literary quality of the video game and also helps with sales and marketing aims of the companies. The study aims to emphasise the importance of subtitle translation, especially in storydriven video games. In this direction, samples selected from Turkish subtitles of the video game called The Last of Us, which has achieved high sales figures all over the world and which had been nominated and won awards in categories including story and narrative in particular. To lay the groundwork for the evaluation in this study, the translation action is discussed in two dimensions, economic and literary. Then, the internal and external contexts, which are thought to influence translation decisions, have been emphasised. Text types and features of video games are examined in the internal context while different approaches and processess are examined in the external context. In this context, the theoretical framework of the study is shaped in the audiovisual translation and in the light of the norms affecting translation process. The Turkish subtitle translation of the selected video game has been analysed by using a descriptive approach and the coupled pairs of Gideon Toury. As a result of the study, it is thought that translation decisions in the target text might be affected by the translation process as well as the translator's decisions. Consequently, it is seen that texts in games are complement to the visual and audio elements. It is important that decisions taken as part of the translation process should be in compliance with this finding. In this research the importance of video game translation in terms of strengthening communication between the player and the game is underlined. In this process, the role of translators as a communication expert and the need for obtaining translation competence via academic translator training are emphasised. Thus, it is thought that this study will contribute to the visibility of video game translation and evaluation in the field of translation studies.

Keywords: video game translation, translation evaluation, translation criticism, video game localization, localization

\section{Giriş}

Günümüzde milyonlarca insan tarafından oynanan video oyunların ${ }^{1}$ ilk örneği, 1947 yılında geliştirilen Cathode Ray Tube Eğlence Cihazı olarak kabul edilmektedir (Tezel, 2016, s. 11). Oyun literatüründe kabul edilen ilk modern oyun örnekleri ise Tennis for Two $^{2}$ ve Spacewar! ${ }^{3}$ isimli oyunlardır. Ardından Pong, Pac-man ve Mario gibi grafik, ses ve içeriği gelişmiş oyunlar bugünkü oyun sektörünün temellerini atmıştır (Ünal \& Batı, 2011, s. XIII). Aradan geçen 60 yılda, oyunlar tüm dünyada popüler bir eğlence kaynağına dönü-

\footnotetext{
${ }^{1}$ Oyun kavramı farklı içeriklerle tanımlanabilmektedir (bkz. O'Hagan \& Mangiron, 2013; krş. Bernal-Merino, 2015, s. 12-18). Frasca video oyunları: "[...] kişisel bilgisayar veya konsol gibi elektronik platformlarda kullanıIan [...] tüm bilgisayar tabanlı eğlence yazılımları" (2001, s. 4) şeklinde tanımlar. Çalışmada incelenecek olan The Last of Us, oyun konsolu PlayStation için geliştirildiğinden, bilgisayar hariç platformları da kapsayan 'video oyun' kavramı kullanılacaktır. Bu kavram çalışmada 'oyun' şeklinde kısaltılacaktır.

${ }^{2}$ https://www.bnl.gov/about/history/firstvideo.php (26 Şubat 2019)

3 http://museum.mit.edu/150/25 (4 Şubat 2019) krş. Akbulut, 2009, s. 45 
şürken, genişleyen erek kitle yelpazesi ve oyun çeşitliliği arasında iki yönlü bir ilişki oluşmaya başlamıştır. Bir yandan farklı ilgi alanlarına ve yaş gruplarına yönelik bulmaca, spor, strateji, macera, rol yapma, korku, platform, simülasyon gibi oyun türleri ile birlikte oyuncu kitlesi genişlerken diğer yandan bu kitlenin farklı ihtiyaçları ve beklentileri doğrultusunda yeni oyunlar piyasaya sürülmektedir.

Küreselleşmenin getirdiği tüketim anlayışı ile birlikte, farklı ülkeler ürünlerinin kendi kültür sınırlarının dışına çıkmasını hedefleyen oyun şirketleri için potansiyel pazarlara dönüşmektedir. ${ }^{4}$ Buna bağlı olarak, farklı dil ve kültürlerde var olabilmek için bir iletişim eylemine ihtiyaç duyulur. Bu ihtiyaç, anlatı özelliği ile ön plana çıkan hikâye odaklı oyunlarda ayrı bir önem kazanır. Sektör dinamiklerini takip edebilen ve hedef kitlesini başka ülkelerde de geniş tutmak isteyen şirketlerin sınırlarını çeviri aracılığıyla aştığı söylenebilir. Oyun çevirisinin önceliği, oyun deneyimini sekteye uğratmadan oyuncuya oyunun kendi anadilinde oluşturulduğu hissini vermek ve kaynak kültürdeki oyuncunun oyundan aldığı keyfe eşdeğer bir deneyim sunmaktır (Mangiron \& O'Hagan, 2006, s. 1415). Bu özelliğin farklı bir dil ve kültür dizgesinde var olmasını sağlayan çeviri eylemi, oyuncuyu anlam dünyasına taşıyarak oyuncu ile oyun arasındaki duygusal bağı kurmaya ve güçlendirmeye yarayan bir temsil gücü haline gelmiştir. Bu bağlamda, oyun çevirisi kendine özgü normlara sahip bir uzmanlık alanı olarak değerlendirilebilir.

Bu çalışma, oyun çevirisinin önemini vurgulamayı amaçlamaktadır. Bu amaç doğrultusunda oyun çevirisi bir uzmanlık alanı olarak ele alınmış, bu uzmanlık alanını kuşatan iç ve dış bağlam somutlaştırılmıştır. Böylesine önemli bir alanda çevirinin rolünün yeteri kadar görünür olmadığı ve çeviri sürecinde ihtiyaç duyulan bilgi, destek ve iletişimin ortaya çıkan ürünü doğrudan ya da dolaylı olarak etkilediği varsayımlarından yola çıkılmıştır. Çalışmanın uygulama bölümünde yapılan çeviri değerlendirmesinin de bu amaca hizmet edeceği düşünülmektedir. Öte yandan, bu değerlendirmenin esas ve öncelikli amacı bütüncenin başarılı ya da başarısız olduğu sonucuna ulaşmak değil, erek metindeki çeviri kararları üzerinden çeviriyi kuşatan normları ve çevirinin önemini görünür hale getirmektir.

\section{Bir Uzmanlık Alanı Olarak Oyun Çevirisi}

Farklı ilgi alanlarına ve yaş gruplarına yönelik geliştirilen çeşitli oyunlar; oyun konsolu, bilgisayar, cep telefonu, tablet ve taşınabilir oyun konsollarında tek başına veya diğer oyuncularla oynanabilmektedir. Bu çeşitlilik, oyun sektörünün sahip olduğu geniş sınırlara ve farklı değişkenlere işaret etmektedir. Erek kitle beklentisinin çeşitliliği ve hızla gelişen teknolojinin etkisiyle oyun sektörü kendi arz ve talebini yaratmakta ve giderek büyümektedir. 2012 yılında toplam geliri 70,6 milyar dolar olan oyun sektörünün 2021 yılında 180,1 milyar dolara ulaşacağı öngörülmektedir (Wijman, 2018). Bunun yanında 2016 yılında Digital Games Research Association (DIGRA) ve Society for the Advancement of the Science of Digital Games (SASDG) tarafından 1st Joint International Conference of DIGRA and FDG $^{5}$ adında oyun araştırmalarına yönelik kapsamlı bir akademik

\footnotetext{
4 https://newzoo.com/insights/articles/global-games-market-reaches-137-9-billion-in-2018-mobile-gamestake-half/

${ }^{5}$ http://todigra.org/index.php/todigra/article/view/66/114 (26 Şubat, 2019)
} 
konferans düzenlenmiştir (Brown \& Bidarra, 2017). Bu gibi etkinlikler, paydaşların farklı konu başlıklarında bilgi paylaşımı yapmalarına ve alanın gelişimine önemli katkılar sağlamaktadır.

Oyun sektörünün dünya genelindeki görünürlüğü artarken, Türkiye özelinde de sektöre yönelik atılan adımların hız kazandığı görülmektedir. Türkiye Oyun Geliştiricileri Derneği (TOGED) ve Ticaret Bakanlığı'nın verilerine göre 2016 yılında 500 milyon dolar olan yerli oyun ihracatı, 2017 yılında önceki yıla göre \%40 artarak 700 milyon dolarlık bir hacme ${ }^{6}, 2018$ yılına gelindiğinde ise $\% 100$ artarak 1 milyar 50 milyon dolarlık hacme ulaşmıştır. ${ }^{7}$ Türkiye'de 2017 yılı itibariyle 30 milyondan fazla aktif oyuncunun ${ }^{8}$ bulunduğu düşünüldüğünde, oyun sektörünün önemi somutlaşmaktadır. Bu doğrultuda; Gaming İstanbul (GIST), Uluslararası Dijital Oyun ve Eğlence Fuarı (GameX) ve Video Oyunları ve Teknolojileri Fuarı (Games Week İstanbul) gibi yüksek maliyetli fuar ve turnuvaların düzenlenmesi bu görünürlüğü artıran örnekler olarak düşünülebilir. TOGED, Oyun Tasarımcıları, Geliştiricileri, Yapım ve Yayımcıları Derneği (OYUNDER), Türkiye Bilişim Derneği (TBD) gibi dernek ve organizasyonların kurulması da alana verilen önemi göstermektedir. Dernekleşme ve örgütlenme ihtiyacı çerçevesinde düşünüldüğünde, alanla ilgili ihtiyaç ve beklentileri ele almak ve sorunlara çözüm bulmak için o alanın uzmanlarının ortak bir platformda bir araya gelmesi önemli bir gelişmedir. Bu durum, oyunlar çerçevesinde oluşan erek kitlenin görünürlüğüne ve kamuoyunda oluşturulmak istenen bilince de işaret etmektedir. Öte yandan sektörün basında görünürlüğünün artması, sektörel raporların ${ }^{9}$ hazırlanması, üniversitelerde ilgili bölümlerin açılması ${ }^{10}$ bu alanın giderek önem kazandığı ve popülerleştiği çerçevesinde yorumlanabilir.

Oyun sektörü, oyun geliştirici firmaların küresel boyutta artması ile birlikte nitelik ve nicelik açısından çeşitlenmiştir. Yukarıda sözü edilen oyun türleri, özellikle teknolojik imkânların ilerleyişinden doğrudan etkilenmiştir. Oyunlardaki hikâye anlatımının içerik ve görsel açıdan zenginleştiği görülebilmektedir. Bu zenginlik, oyunların geliştirilme aşamasında aktör çeşitliliğine işaret etmektedir. Özellikle AAA olarak sınıflandırılan yüksek bütçeli oyunlarda senarist, görüntü yönetmeni, mühendis, metin yazarı, editör, müzisyen, teknisyen, tasarımcı, kalite kontrol uzmanı gibi farklı aktörlerin ortak amacı, oyun içinde kurulan dünyada sürükleyici bir deneyim sunmaktır (O'Hagan \& Mangiron, 2013, s. 16-17). Bu oyunlarda grafik, ses ve metinsel içerikten oluşan üçayak, bütünleyici bir yapı ile oyun deneyimini şekillendirir. Görsel ve işitsel içerik, kültürel farklılıklara bağlı değişkenlik gösterse de oyuncu tarafından anlaşılabilir. Bir diğer deyişle, oyuncu kendi

\footnotetext{
${ }_{7}^{6}$ http://www.toged.org/turkiye-yerli-oyunlardan-700-milyon-dolar-kazandi (4 Ağustos 2018).

7 https://www.haberturk.com/yerli-oyun-ihracati-1-milyar-dolari-gecti-2295898-teknoloji (1 Mart 2019).

8 https://www.slideshare.net/GaminginTurkey/turkey-game-market-2017-report-gaming-in-turkey/ (5 Ağustos 2018).

9 https://www.slideshare.net/ozanamrasaydemir/trkiye-oyun-sektr-2016-raporu-ve-gaming-in-turkey (5 Ağustos 2018), https://www.slideshare.net/GaminginTurkey/turkey-game-market-2017-report-gaming-inturkey/ (5 Ağustos 2018) ve http://www.ankaraka.org.tr/tr/dijital-oyun-sektoru-raporu_3414.html (5 Ağustos 2018).

${ }^{10}$ Bahçeşehir Üniversitesi ve İstanbul Bilgi Üniversitesi'nde Dijital Oyun Tasarımı Bölümü, Doğu Akdeniz Üniversitesi Animasyon ve Oyun Tasarımı Bölümü, Hacettepe Üniversitesi Bilgisayar Animasyonu ve Bilgi TeknoIojileri Programı, TED Üniversitesi Dijital Oyun Geliştirme Sertifika Geliştirme Programı.
} 
kültürel bağlamında aşina olmadığı bir manzara ya da müzik türü ile oyunda yaratılan evrende kalabilir. Ancak, özellikle hikâye anlatımında yazınsal içeriğin önem taşıdığı oyunların farklı kültürlerdeki oyuncularda anlam kazanması için çeviri yolu ile yeniden üretilmesi gerekir. Bu bilgiler ışı̆ıında, oyunların çevrilme ihtiyacının ekonomik ve yazınsal olmak üzere birbirine bağlı iki boyutta şekillendiği düşünülebilir.

Oyun çevirisi; sosyal, ekonomik ve kültürel görünürlüğü bağlamında çeviribilim için bir özel alan olarak değerlendirilebilir. Bu özel alanın akademik boyutta ele alınabilmesi için sınırlarının çizilmesi ve normlarının betimlenmesi gerekir. Bu aşamada kavramlara değinmek bir başlangıç noktası sunabilir. Literatüre bakıldığında çeviri alanında yerelleştirmenin ${ }^{11}$ farklı tanımlarla ifade edildiği görülür. Örneğin Özlem Berk, Kuramlar ışığında Açıklamalı Çeviribilim Terimcesi'nde yerelleştirme kavramını “...yazılım ürünleri ve web sitelerinin başka bir dil, kültür ve hukuk ortamında kullanılabilmesi için söz konusu erek dizgeye uyarlama süreci..." (2005, s. 164) olarak tanımlar. Işın Bengi-Öner yerelleştirmeyi "...ana hatlarıyla yazılım ve örün ürünlerinin ulaşacağı kitleye göre kullanıma hazır hale getirilmesi..." (2006, s. 34) olarak yorumlar ve çeviriyi bu eylemin bir parçası olarak görür. Mine Yazıcı ise 'lokalizasyon' kavramını “...ürünün dijital ortam koşullarına uyarlanarak yerel pazara sunulması..." şeklinde ifade eder (2007, s. 125). Öte yandan Canım Alkan çeviri ve yerelleştirme kavramlarını hem akademik hem de sektör boyutunda incelemiş ve bu kavramların ortak ve ayrışan yönlere sahip olduğunu vurgulamıştır (2013). Bu farkı görüşlerin oluşmasında tanımlamayı yapanların artalanı kadar, yerelleştirme eyleminin genişliği de etkilidir. Literatürde çevirinin, birçok basamaktan oluşan yerelleştirme sürecinin bir parçası olduğu sıkıkla karşımıza çıkmaktadır (bkz. Bernal-Merino, 2015, s. 2; Pym, 2014, s. 42. Krş. Gouadec, 2007, s. 37). Dolayısıyla bu çalışmada çeviri eylemi ve yerelleştirme iç içe süreçler olarak değerlendirilecektir. Ancak, çevirinin bu süreçte bir adım olarak görülmesi, çeviri eylemini mekanik bir dilsel aktarım olarak sınırlandırmamalıdır. Özellikle bu dijital ürünler dil düzleminde bir hikâye anlatma kaygısı taşıyan oyunlar olduğunda, çeviri sürecine sanatsal bir katman daha eklenmektedir. Özetle oyunlar söz konusu olduğunda, yazııım yerelleştirme ve görsel-işitsel bağlamda yaratıcı bir çeviri süreci devreye girer (Munday, 2008, s. 190). Bu çalışmanın bütüncesi yalnızca oyun içi altyazı metinlerinden oluştuğundan bu metinlerin yaratıcı aktarım süreci 'çeviri' ifadesi ile karşılanmıştır.

Yukarıda normlarından söz edilen çeviri sürecini yöneten çevirmen ${ }^{12}$, teknolojiye hâkim, kültürel aktarım ve iletişim uzmanı bir aktör olarak hareket etmelidir. Bu aktör, iki farklı erek kitleyi göz önünde bulundurmalıdır. Bunlardan ilki ürünlerini (çevirileri) satacağı veya çalıştı̆̆ı oyun şirketleri, diğeri de bu ürünlerin asıl erek kitlesi olan oyuncu-

\footnotetext{
${ }^{11}$ Çeviribilim terminolojisinde yerelleştirmenin 'localization’ kavramı ile karşılandığını görmekteyiz. Ancak bazı uzmanlık alanlarında, alana özgü yerleşik ifadelerin tercih edildiği görülmektedir. Bu alanlardan biri olan video oyunlarda, yerelleştirme ve lokalizasyon kavramlarının her ikisinin de kullanılabildiği görülmektedir bkz. Gaming in Turkey: https://www.gaminginturkey.com/tr/oyun-lokalizasyon-ve-yerellestirme-gaming-in-turkey/ (4 Ocak 2019). Çeviribilim penceresinden gerçekleştirilen bu çalışmada Türkçe literatürde de kullanıldığı görülen yerelleştirme ifadesi de tercih edilmiştir.

${ }^{12}$ Bu çalışmada, piyasada çeviri işini üstlenen aktörlerin farklı artalan ve eğitime sahip olduğu görüldüğünden, çeviri işini üstlenen kişiler bu özelliklere bakılmaksızın çevirmen kavramı ile tanımlanmıştır.
} 
lardır. Her iki erek kitlenin beklentisi iç içe tanımlanabilir. Özellikle zengin bir anlatı dünyasına sahip oyunlarda çeviri eyleminin oyuncunun kültür bağımlı beklentilerini çözümleyebilen, diğer bir deyişle yaşadığı toplumun kültürel normlarına hâkim ve oyun metinlerinin doğasındaki duyguları erek kültüre aktarabilen yaratıcı çevirmenler tarafından yürütülmesi işlevsel olacaktır. Bu durumun, oyun şirketlerinin erek kitle odağında beklentilerini karşılayabilecek ve oyuncunun oyunla güçlü bir bağ kurmasını sağlayacak bir çeviri beklentisine işaret ettiği düşünülebilir. Ancak çeviride bu beklentinin amacına ulaşmasını etkileyen farklı değişkenler vardır. Bu çerçevede bir sonraki bölümde, çevirinin anlatı dünyası kurmadaki rolünü değerlendirebilmek için çeviriyi kuşatan iç ve dış bağlam unsurları betimlenecektir. Bu sayede çalışmanın uygulama bölümünde incelenecek çeviri kararları, ilgili çeviri gerçekleri kapsamında değerlendirilebilecektir.

\section{Video Oyunlarda Çeviri Değerlendirmesini Etkileyen İç ve Dış Bağlam Dinamikleri}

Tüm çeviri süreçlerinde olduğu gibi, oyun çevirisini yönlendiren normlar da çeviri ürünü ve/veya çeviri sürecinin incelenmesi ile saydamlaştırılabilir. Kaynak metnin içinde bulunduğu normlar bağlamında erek metne dönük çözümlenmesi işlevsel bir çeviri süreci için anahtardır. Bu süreçte kaynak metnin içinde bulunduğu bağlam görsel-işitsel ürünler çerçevesinde değerlendirilebilir. Görsel işitsel ürünler, çok katmanlı iletişim özellikleri sayesinde erek kitlesiyle farklı duyular üzerinden etkileşim kurmaktadır (Okyayuz \& Kaya, 2017, s. 51-52). Bu etkileşimi oluşturan metin içi ve metin dışı öğeler vardır. Başarılı bir görsel-işitsel çevirinin temelinde ürün ve amaçlanan işleve dair bir içgörü ve anlayış yatar (Diaz-Cintas \& Remael, 2014, s. 13). Bu gerçeklikler değerlendirme sürecindeki ölçütlere ışık tutar ve metin türüne, iş tanımına ve erek kitle beklentisine göre değişiklik gösterebilir. Bu nedenle, The Last of Us oyununun Türkçe altyazı çevirisi değerlendirilmeden önce bu uzmanlık alanına özgü normların metin içi ve metin dışı bağlamda irdelenmesi gerekli görülmüştür. Oyun metni gelenekleri ve bu geleneklerin çeviri kararları ile bağlantısı iç bağlamı oluştururken, çeviri sürecini şekillendiren aktörler ve gerçeklikler dış bağlam çerçevesinde irdelenmiştir. Erek metni oluşturan çeviri kararları, iç ve dış bağlamın bir sonucu olarak ele alınmıştır. Bu aşamada, kaynak metnin türüne bağlı unsurlar değerlendirme için somut bir başlangıç noktası oluşturabilir.

Oyun metinleri, birçok çalışmada kendi alt türlerine ve metin geleneklerine sahip kapsayıcı bir başlık olarak ele alınmaktadır (bkz. O’Hagan \& Mangiron, 2013, s. 124128; Bernal-Merino, 2008, s. 34) ve oyunun kurmaca dünyası ve gerçek dünyaya yönelik hazırlanan farklı metin türleri içerebilir. Örneğin, yoğun renk ve efektlerin kullanıldığı oyunlarda, olası epilepsi nöbetlerine ve görme bulanıklıklarına yönelik uyarı metinleri, telif hakları ve kullanıcı sözleşmeleri, oyunun satılacağı pazara göre şekillenen hukuki metinler, basılı ve dijital tanıtım metinleri, kullanım kılavuzları, kurulum dosyaları gibi metinler hazırlanmaktadır.

Oyunun kendi yarattığı evren de tıpkı gerçek dünyadaki gibi çeşitli yazılı ve sözlü metinlerden oluşur. Yardım iletileri, menü metinleri, sistem mesajları gibi bilgilendirme ve yönlendirme amaçlı kullanıcı ara yüzü metinleri, anlatımcı ve betimleyici pasajlar, gazete, poster, harita, tabela gibi grafiğe gömülü metinler ve oyunun içindeki sinematik sahneler bu metin türlerine örnek olarak gösterilebilir. Oyun evreni, gerçekte de olduğu 
gibi hukuk, teknik, reklam, haber, yazın gibi farklı alanlara ait metinler içerebilir. Görüldüğü gibi çevirmen, tüm bu metin türlerini çevirirken, kaynak ve erek metnin geleneklerine duyarlı olmalıdır.

Farklı metin türlerinin birleşimi olan oyun metinlerinin çevirisinde erek kültürün gelenek ve normları da süreci etkiler. Bu noktada metinlerin melez (hybrid) bir özellik kazandığı düşünülebilir. Anna Trosborg, melez metinleri diller ve kültürlerarası bir iletişim süreci içinde tanımlamaktadır. Bu süreç eğitim, bilgilendirme, tanıtım veya eğlendirme gibi farklı iletişimsel amaçlar doğrultusunda gerçekleşebilir (1997, s. 146). Bu açıdan bakıldığında farklı özellikler taşıyan oyun metinlerinin Trosborg'un melez metin tanımıyla örtüştüğü noktalar olduğu söylenebilir.

Yukarıdaki bilgilerden hareketle oyun metinlerinin erek dilde oluşturulması alan, metin ve kültür edinci gerektirdiği söylenebilir. Bunun nedeni erek kültürdeki oyuncunun oyunun anlam dünyasına girebilmek için kaynak kültürdeki gibi farklı işlevlere sahip metinlere ihtiyaç duymasıdır. Oyuncu, bilmediği bir dilde de çeşitli simgesel yönergeleri takip ederek veya daha önceki deneyimlerinden yararlanarak bazı oyunlarda görece ilerleyebilir. Bununla birlikte, yazınsal anlatım özelliğini ön plana çıkaran hikâye odaklı oyunlarda geliştiricinin sunmak istediği anlatı dünyasının oyuncu tarafından deneyimlenmesi, belirleyici bir özellik olarak görülebilir. Bu noktada oyuncu ve geliştiricilerin beklentisi iç içe tanımlanabilir. Oyuncunun oyundan beklentisinin karşılanması, farklı oyunlar için potansiyel müşteri olmasını sağlayacak ve oyunların bu doğrultuda tasarlanmasının önünü açacaktır. Örneğin Avrupa Komisyonu tarafından fonlanan "The Fun of Gaming: Measuring the Human Experience of Media Enjoyment" (FUGA) ${ }^{13}$ projesinde oyuncuların bilişsel süreçleri incelenerek hangi içeriğe nasıl tepki verdiği gözlemlenmiştir. Bu araştırma çeviri eylemi bağlamında da yorumlanabilir. Oyuncunun oyun evreninde kalması ekonomik kaygılarla da tetiklenen temel bir beklenti olduğundan, oyunlar farklı bir kültürde yeniden yaratıldığında da oyuncu kitlesine eşdeğer bir deneyim sunması beklenecektir.

Çevirinin metin dışı bağlamı, anlatı dünyasını yazılı metin boyutunda aktarma aşamasında alınan çeviri kararlarını şekillendirmektedir. Bu nedenle, metin türü kadar erek metnin üretildiği ortam ve süreçte yer alan aktörlerle ilgili dinamikler de değerlendirme sürecine etki ettiği için dikkate alınmalıdır. Örneğin karakterlerin geçmişi, kişiliği ve hayatını anlatan bilgi dosyalarının sağlanmasıyla çevirmen, kaynak kültürde yaratılan bir karakteri mikro düzeyde sözcük seçimleri ve makro düzeyde çeviri stratejileri ile erek kültürde oluşturmak için gerekli bilgiyi edinebilir. Bu bilginin eksikliği, karakterin anlamsal derinliğinin oluşmasını güçleştirebilir. Oyun geliştiricileri bu sürece farklı düzeylerde önem verdiği için kimi zaman gerekli bilginin sağlanamaması söz konusu olabilir (bkz. O’Hagan \& Mangiron 2013, s. 136-138. Krş. Tishin, 2014, s. 35-39). Çevirmeni yaratılan dünyanın dışında tutan ve bilgileri 'el yordamı ile' aramasına neden olan bu durum, erek oyuncu kitlesine de yansıyabilir. Örneğin ihtiyaca göre oyunda birden fazla yerde kulla-

${ }^{13}$ http://fuga.aalto.fi/ (1 Mart 2019) 
nılabilecek kalıp ifadelerden oluşan 'ara metinlerin' kullanıldığı sahnedeki ortam, kişi sayısı, cinsiyet gibi bağlam bilgisinin çevirmene sağlanmaması çeviri tercihlerinin yine tahmin ile sürdürülmesine neden olabilir. ${ }^{14}$

Çeviriyi gerçekleştiren aktörlerin çevrilmiş metni kalite kontrol sürecinden önce oyun bağlamı içinde görebilmesi oldukça önemlidir (Fung, 2012, s. 18). Bunun gerçekleşmediği durumlarda metnin kullanıldığı ortam açıklanmamışsa, çevirmen bağlamı ve sahneyi tahmin ederek çözümleyecektir. Öte yandan, yapılan çevirilerin başka bir birimde toplanması ve çevirmenlerin dâhil olmadığı farklı süreçlerde test edilmesi olası hataların giderilmesinin veya gerekli düzeltmelerin tespit edilmesini engelleyebilir. Bu durumda ideal senaryo, çevirmenin de dâhil olduğu bir değerlendirme sürecinin yürütülmesi olarak görülebilir.

Bunların yanı sıra, farklı gerekçelerle bilgisayar destekli çeviri araçlarının kullanılmadığı ve metin dosyalarının Excel tabloları üzerinde paylaşıldığı örnekler de görülmektedir (krş. Fidaner, 2009). Özellikle metin hacmi yüzbinlerce kelimeye varabilen oyunlar düşünüldüğünde kaliteli bir çeviri elde etmek zorlaşabilir. Oyun çevirisi sürecinin gerçekleri olarak tanımlanabilecek bu değişkenlerin, bu çalışmanın konusu olan The Last of Us çeviri sürecinde alınan kararları da etkilediği düşünülebilir. ${ }^{15}$

\section{Kuramsal Yaklaşım ve Yöntem}

Bu çalışmada, oyun çevirisinin görsel-işitsel çeviri kapsamında değerlendirilebileceği (Diaz-Cintas, 2008, s.2) üzerinde durulmuştur. Ses efektleri, animasyon, görsel öğelerden oluşan ve bu çalışmanın odaklandığı gibi bir hikâye anlatımına sahip olan içeriklerin altyazı ve dublaj ile sunulması, bu türün görsel-işitsel ürünler ile pek çok ortak noktası bulunduğunu göstermektedir. Yves Gambier ve Henrik Gottlieb’in görsel- işitsel çeviri bağlamında sıraladığı dört temel özellik aşağıdaki şekilde özetlenebilir:

1. Takım çalışmasını anahtar öneme sahip olması

2. Çevirmenlerin çoğunlukla senaryo, diyalog ve taslak gibi geleneksel eşdeğerlik çerçevesinde bir aktarıma uymayan, yaratıcılık gerektiren metinlerle çalışması

3. Görsel-işitsel çeviride geçerli olan ölçütlerin anlaşılabilirlik, erişilebilirlik ve kullanılabilirlik olması. Bu metinlerde işlevin okunabilirlik kalitesinin ve kabul edilebilirliğinin ötesine geçmesi ve genellikle dilsel normlarla sınırlı olması. Yeni medyanın bizleri, çeviriye yönelik yerleşik bakışı olduğu kadar yazılı ve sözlü dili yeniden gözden geçirmeye itmesi. Bu durumda, hata analizinin değerlendirme için tek ölçüt olmaması

4. Akademi ve sektör arasındaki boşluğun daha çok ifade edildiği bu süreçte, yukarıdaki özelliklerin eğitim için de çıkarımlar içermesi (2001, s. xi)

Yukarıdaki özelliklerden yola çıkarak; oyun çevirisini kuşatan normların süreçteki aktörlerin işbirliğinin ve iletişimin önem kazanması, metinlerin yaratıcılıkla ve erek kültürde gerçeklik kazanabilecek şekilde aktarılması ve bir anlatı oluşturması çerçevesinde şekillendiği söylenebilir. Bu durum, çevirinin normlarla şekillenen bir eylem olduğunu bir

\footnotetext{
${ }^{14}$ Bkz. bu çalışmada 2. 3. ve 4. örnek

${ }^{15}$ Bu dinamikler, The Last of Us oyununun Türkçe dil desteğini sağlayan şirket ile oyunun çeviri sürecine yönelik yapılan görüşmelerden edinilen bilgiler dikkate alınarak derlenmiştir.
} 
kez daha gözler önüne serer. Bu noktada Gideon Toury'nin betimleyici çeviri yaklaşımının temelini oluşturan normlardan söz edilebilir ve bu normlar üründen yola çıkarak betimlenebilir. Bu betimleme, çevirmenin çeviri sürecinde aldığı kararları ve süreci kuşatan katmanları somutlaştırmaya yardımcı olmaktadır (1995, s. 53-70). Böylelikle, üründen yola çıkarak süreç artsüremli olarak betimlenebilir. Çeviriyi erek dizgede gerçekliği bulunan bir olgu olarak tanımlayan Toury'den $(2012$, s. 6) yola çıkarak yaratıcı bir çeviri süreci gerektiren oyunların çeviri sürecinde kaynak metin oyuncusunda yarattığı etkinin erek metinde de oluşturup oluşturulmadığını görebilmek için erek metnin kendi içinde incelenmesi gerekir. Bu bağlamda, ancak oyuncuyu oyun dünyasından uzaklaştıran erek dil tercihleri oluştuğunda kaynak metne dönme ihtiyacı doğar.

Bu süreçte, Toury'nin betimleyici çeviri çalışmaları kapsamında ele aldığı "sorunçözüm çifti" akla gelmektedir. Toury'nin yaklaşımında odak noktası çeviri ve erek dizge olduğundan betimleyici araştırmalarda erek metin öncelikle diğer metinlerle ilişkisi bağlamında ele alınır. Ardından erek ve kaynak metin karşılaştırılarak aradaki eşdeğerlik betimlenir. Erek metin çözüm, kaynak metin ise sorun olarak adlandırılır. Yapılan değerlendirmelerle alınan çeviri kararları çeviri ürünlerdeki sonuçtan (çözümden) bakarak varsayımsal çerçevede yorumlanabilir (1985, s. 25-28).

Bu çalışmada yapılan incelemede kaynak ve erek metin, bir "sorun-çözüm çifti" olarak görülerek aralarındaki ilişkinin betimlenmesi için ele alınmıştır. Araştırmacılar tarafından The Last of Us oyunu Türkçe ve İngilizce altyazı seçenekleri ile oynanmış, bir diğer deyişle oyun içi metinler incelenmiştir. Bu süreçte ilk önce bağlam bilgisi verilerek ilgili oyun sahneleri betimlenmiştir. Ardından, oyundan alınan görseller eklenmiştir. Daha sonra "çözüm" olarak kabul edilen erek metnin (EM) hangi "sorunlar" sonucunda oluştuğunu somutlaştırmak için kaynak metne (KM) dönülmüştür. Bir kaynak metin farklı tercihlerle erek dizgede yeniden yaratılabilir. Bu bilgi doğrultusunda, araştırmacılar tarafından sunulan öneriler, eleştirilen bağlamı netleştirme amacına hizmet etmektedir. Bir başka deyişle, anlam dünyasını oluşturma çerçevesinde sunulan alternatif "çözümlerdir".

Yapılan değerlendirme farklı duygu ve söylemleri doğal dil kullanımı içinde erek kültüre aktarma odağında şekillenmiştir. Bir başka deyişle, çeviri bu dünyayı erek kitleye aktarabildiği ölçüde işlevseldir. Metnin duygulara hitap eden anlatı işleviyle kurulan anlam dünyasında neşe, hüzün, öfke gibi duygular olduğundan çeviri tercihleri 'anlam dünyasını kurma amacı' çerçevesinde değerlendirilecektir. Öte yandan, çalışma kapsamında çevirinin önemi erek metin üzerinden değerlendirildiği için süreçteki etkenler, çeviri değerlendirmesini etkilediği düşünülen öğeler olarak vurgulanmıştır.

Yukarıda kuramsal çerçevesi çizilen değerlendirmeyi yapmak için amaçsal örnekleme yöntemi ile örnek seçilmiştir. Bu yöntemde, örnekler önceden belirlenmiş eleştirel ölçütler doğrultusunda seçilmektedir (Saldanha \& O’Brien, 2014, s. 34). Çalışmanın amacı çevirinin önemini vurgulamak olduğundan, erek kültürde yadırgatıcı unsurlarla anlatı dünyasını sekteye uğrattığı düşünülen erek metin kararlarının belirginleştirilmesi önem kazanmıştır. Böylelikle, bu vurgunun yansıtılabileceği örnekler bu amaçtan yola çıkarak bütünceye dâhil edilmiştir. 


\section{Bütünce}

The Last of Us, Amerikan Naughty Dog oyun şirketi tarafından geliştirilmiş ve 2013 yılında Sony Computer Entertainment tarafından PlayStation 3 oyun platformuna özel olarak piyasa sürülmüştür. Oyunun piyasaya sürülmesinden sekiz ay sonra, ana karakterlerden Ellie'nin hayatından kesitler içeren Left Behind isimli bir indirilebilir ek paket yayınlanmıştır. PlayStation 4 için ise 2014 yılında The Last of Us Remastered piyasaya sürülmüştür. Orijinal hikâye ile Left Behind içeriğini aynı pakette sunan bu sürüm, oyunun içeriğinde herhangi bir değişiklik taşımamakla beraber, gelişmiş bir teknolojiye sahip PlayStation 4 platformunda daha yüksek ekran çözünürlüğü ve performans ile oynanabilmesi için hazırlanmıştır. Oyunda İngilizce, Fransızca, İtalyanca, Almanca, İspanyolca, Portekizce, Felemenkçe, Danca, Fince, Norveççe, İsveççe, Çekçe, Yunanca ve Türkçe metin desteği ve İngilizce, Fransızca, İtalyanca, Almanca, İspanyolca ve Portekizce seslendirme desteği bulunmaktadır. ${ }^{16}$ Oyunun resmi Türkçe metin desteği, Türkiye'de kurulmuş bir oyun yerelleştirme şirketi tarafından sağlanmıştır. ${ }^{17}$ Uluslararası video oyun derecelendirme kurulu Entertainment Software Rating Board [ESRB] tarafından, 17 yaş üzerine uygun (Mature-M) olarak derecelendirilen hayatta kalma-korku, aksiyon-macera türündeki bu 2017 yılında ise ilk oyunun devamı niteliğindeki The Last of Us: Part II duyurulmuştur. Tüm bunlar, oyunun oyuncu kitlesi ile kurduğu bağı destekler nitelikte bilgilerdir.

The Last of Us, insanları saldırgan yaratıklara dönüştüren bir mantar türünün yayılmasından yirmi yıl sonra, 2033 yılında Amerika Birleşik Devletleri'nde geçmektedir. Hikâyenin ana kahramanları Joel isimli orta yaşlı bir erkek ile Ellie isimli genç bir kızdır. Oyun piyasaya çıktığı tarihten bu yana en iyi senaryo, müzik, oyunculuk, hikâye anlatımı, seslendirme, grafik gibi çeşitli kategorilerde 200'ün üzerinde ödül kazanmıştır. ${ }^{18}$ Kazandığı ödüller arasında BAFTA Video Oyunu Ödülleri'nde 'Hikâye', Game Developers Choice Awards'da 'En İyi Anlatım', D.I.C.E. Ödülleri'nde 'Hikâyede Olağanüstü Başarı' ödülü bulunmaktadır. ${ }^{19}$ Oyunun, toplamda 17 milyonun üzerinde kopyası satılmıştır. ${ }^{20}$ Tam da bu nedenle, çevirinin oyuncu için kurulan dünyadaki rolünü somutlaştırabilmek için The Last of Us bütünce olarak seçilmiştir.

\section{Uygulama}

Bu çalışmada, nitel araştırma yöntemi çerçevesinde araştırma ve araştırmacıların deneyimleri bir bütün olarak görülmektedir. Dolayısıyla araştırmacıların oyun dünyasındaki tecrübeleri ve oyun çevirisi sektöründeki profesyonel deneyimleri de araştırmanın bütüncesini oluşturan The Last of Us'ın seçilmesinde ve çeviri kararlarının değerlendirilmesinde etkili olmuştur. Öte yandan, çeviri değerlendirmesinde nesnellik önemli bir tartışma konusudur. Değerlendirme eyleminin doğası gereği, eylemi hayata geçiren birer

\footnotetext{
${ }^{16}$ https://store.playstation.com/tr-tr/product/EP9000-CUSA00556_00-THELASTOFUS00000/ (19 Şubat 2019)

17 Gizlilik anlaşmaları nedeniyle oyunun dil desteğini sağlayan şirketin adı belirtilmemiştir.

${ }^{18}$ https://www.playstation.com/en-us/games/the-last-of-us-remastered-ps4/ (22 Şubat 2019)

19 https://www.imdb.com/title/tt2140553/awards (4 Ağustos 2018)

20 https://twitter.com/Naughty_Dog/status/1007320235731488770 (1 Mart 2019)
} 
özne olarak araştırmacıların varlığı, farklı kültürel katmanları ve art alanları öznelliği beraberinde getirmektedir. Bu öznelliği kabul edilebilir bir seviyede tutmak için, değerlendirme sınırlarının çizilmesi ve hata kavramının somutlaştırılması önem taşır. Aksi halde yapılan değerlendirme bir "hata avcılığı" ${ }^{21}$ halini alacaktır. Araştırmacının sadece kendi beğenisi ve istekleri doğrultusunda şekillenen bir öznellik ile hata bulması ile erek metni mevcut iş tanımı ve özel alanın gereklilikleri çerçevesinde hatalı bulması arasında fark vardır. Bu çalışmada ise çeviri kararlarının duruma ve amaca neden uygun olmadığını gösteren değerlendirmelerle olabildiğince nesnelliğe yaklaşmak hedeflenmiştir. Amaç, çevirinin anlam dünyası oluşturma ölçütüne göre bir üst değerlendirme yapmak olduğundan, hata kavramını somutlaştırmak önemlidir. Bu çalışma özelinde muğlaklık, anlaşılmazlık, yanlış bilgi verme gibi anlamın farklı aktarıldığı tercihler ve doğal olmayan ya da bağlama uymayan dil kullanımı gibi yadırgatıcı unsurlarla oyuncuyu oyunun anlatı dünyasından uzaklaştırarak gerçekliği sekteye uğratan kararlar hata olarak ele alınacaktır.

\section{1. Örnek}

Bağlam bilgisi: Bu sahnelerde, Joel ve Sarah'nın karakterlerine yönelik ipuçları oyuncuya sunulmaktadır. Joel, ekonomik sorunları olan, duygularını gösteremeyen ancak kızına olan sevgisi davranışlarından anlaşılan bir karakterdir. Neşeli bir kız çocuğu olan Sarah ile Joel arasında güçlü ve samimi bir baba-kız ilişkisi olduğu anlaşılmaktadır.

Bu sahnede, koltukta uyuyakalan Sarah uyanarak eve gelen babasına hoş geldin der, işyerinde gününün nasıl geçtiğini sormasına rağmen bir cevap alamaz. Ardından çocuksu bir sevinçle hediyesini verir. Şaşkınlıkla kutuyu açan Joel, içinden çıkan kol saatini incelerken bir tepki vermez. Sarah, saati beğenip beğenmediğini sorar. Joel saatin bozuk olduğunu ima ederek kızını kızdırmaya çalışır. Sarah endişeyle saati kontrol eder ve çalıştığını anlayınca babasına tatlı-sert kızar. Joel, kızına hediyeyi almak için parayı nereden bulduğunu sorar. Sarah ise şakayla karışık bir cevap verir.

\footnotetext{
${ }^{21}$ Kavramın kullanımı için krş. Bengi-Öner, 1999, s. 137-148, Bengi-Öner, 1999, s. 149- 154 ve İnce, 1997, s. 253-259.
} 


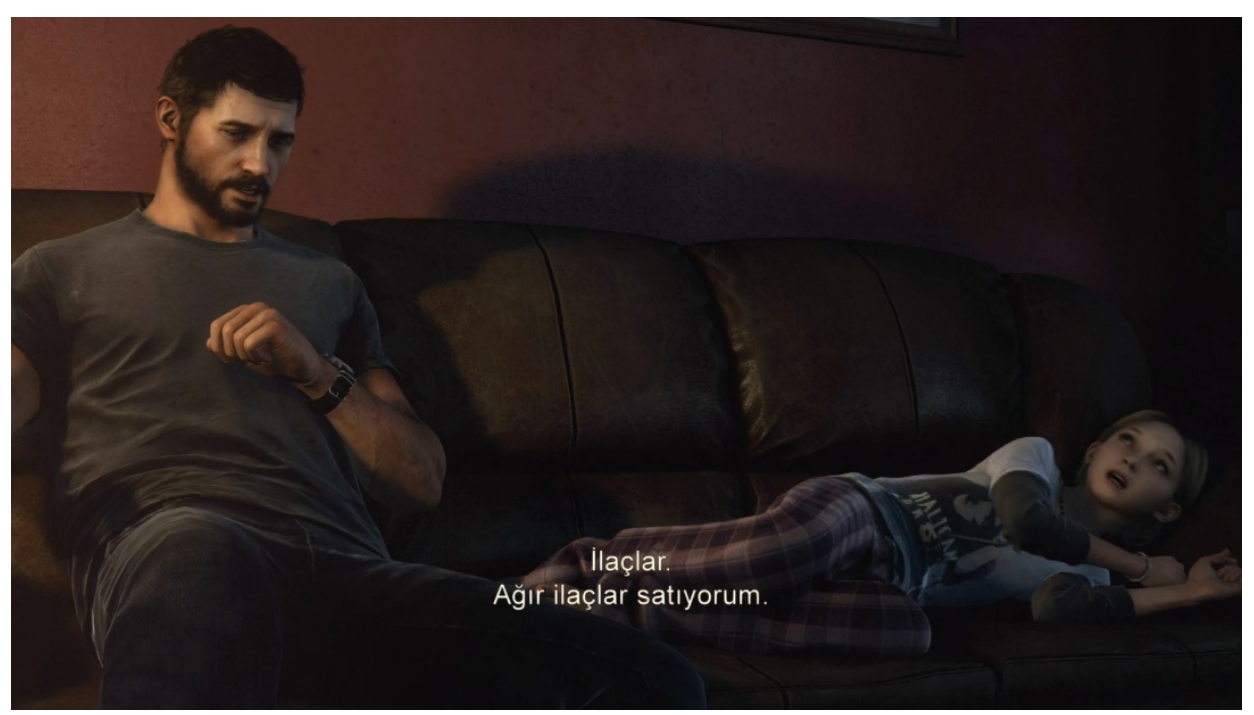

Resim 1 


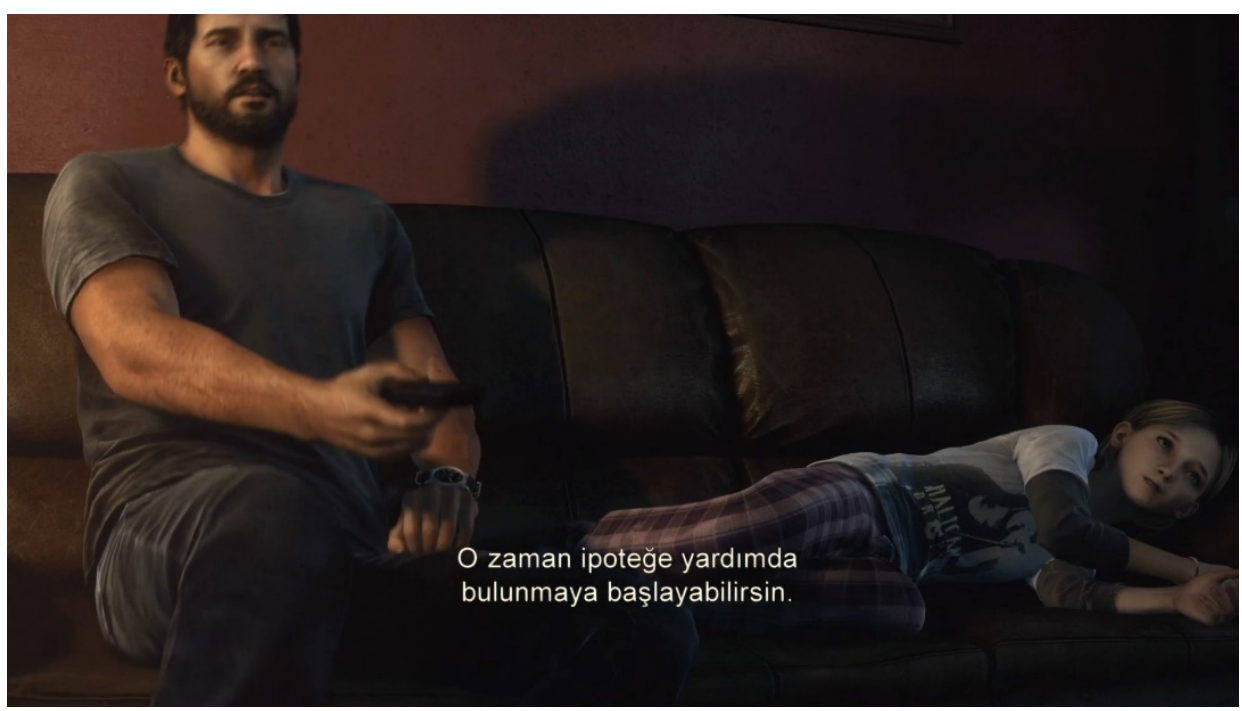

Resim 2

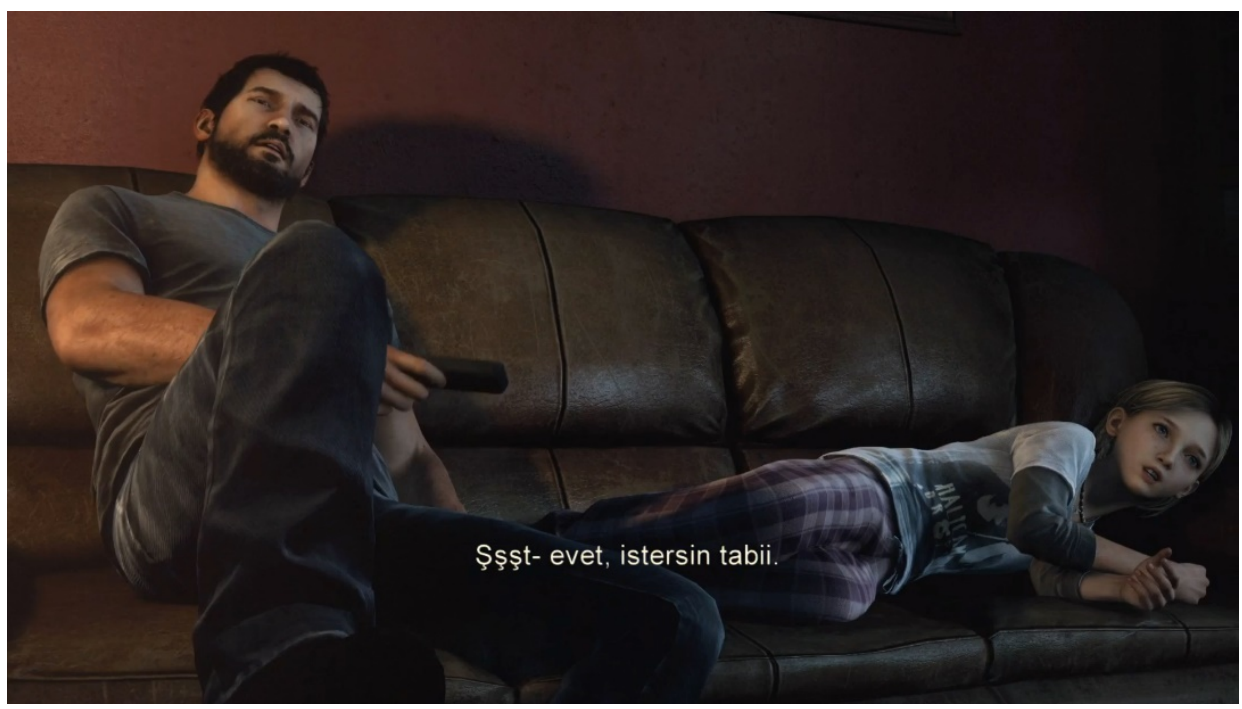

Resim 3 


\section{EM:}

Sarah: Ilaçlar. Ağır ilaçlar satıyorum.

Joel: Ah güzel. O zaman ipoteğe yardımda bulunmaya başlayabilirsin.

Sarah: Şşşt - evet, istersin tabii.

\section{KM:}

Sarah: Drugs.. I sell hardcore drugs.

Joel: Oh good. You can start helping out with the mortgage then.

Sarah: Stsh - yeah, you wish.

\section{Öneri:}

Sarah: Uyuşturucu. Acayip uyuşturucular satıyorum.

Joel: Oo güzel... ev kredisine de yardım et o zaman.

Sarah: Hah, daha çok beklersin.

Değerlendirme: EM'nin karakterlerin söylemiyle uyumlu olması, oyuncuyu iletişime dâhil etmekte yardımcıdır. Bir başka deyişle, çeviri olduğunu hissettirmeyen ve günlük dilden uzaklaşan yadırgatıcı ifadeler içermeyen tercihlerin işlevsel olacağı söylenebilir. "ilaçlar. Ağır ilaçlar satıyorum." karşılığı KM'ye kelime düzeyinde bağlılık kaygısıyla ya da Sarah'nın çocuksu ifadelerini yansıtmak için seçilmiş olabilir. Bu karakteri yansıtan farklı çeviri kararları da alınabilir. Örneğin Sarah'nın çocuksu bir abartı ile "hardcore” sözcügünü de karşılayan 'acayip uyuşturucular satıyorum.' yanıtını vermesi önerilebilir.

Joel’un “Ah güzel. O zaman ipoteğe yardımda bulunmaya başlayabilirsin." ifadesi işlev bakımından anlamı bozmasa da, yadırgatıcı unsurla doğal dil kullanımından uzaklaşarak oyuncuyu duraksatabilir. Bankadan ev için çekilen kredi anlamına gelen "mortgage" ifadesini karşılamak için "ipotek" sözcüğünün kullanılması anlamı yanlış aktarmaktadır. Bu çerçevede, "ev kredisine de yardım et o zaman" gibi bir tercih önerilebilir.

Sarah'nın cevabı da mizah duygusunu günlük dil kullanımı ile yansıtmalıdır. Çeviri tercihlerine bakıldığında "Şşşt - evet, istersin tabii" ifadesindeki "şşşt" ünleminin günlük dil kullanımından uzak olduğu söylenebilir. Çünkü "Şşşt" ünlemi genellikle susturma ya da seslenme için kullanılır. Bu çerçevede yine karakterin çocuksu söylemine uyduğu düşünülen "Hah, daha çok beklersin." karşılığı önerilebilir. 


\section{2. Örnek}

Bağlam bilgisi: Joel ve ortağı Tess yıkıntı bir binanın içinde baş başadır. Oyuncu, ilerlemek için kapının önündeki engele giderek etkileşim tuşuna bastığında tavanın çökmesine neden olur.

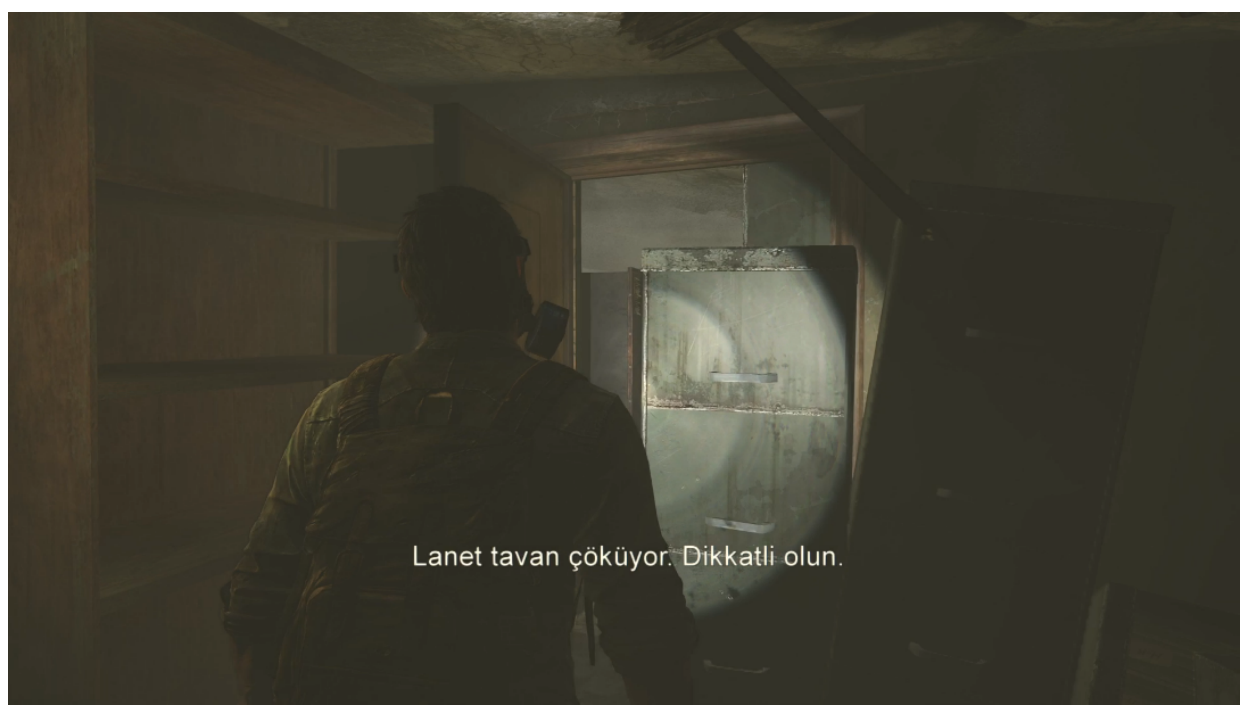

$\operatorname{Resim} 2$

EM:

Joel: Lanet tavan çöküyor. Dikkatli olun.

KM:

Joel: Damn ceiling's falling apart. Be careful.

Öneri:

Joel: Lanet tavan çöküyor. Dikkat!

Değerlendirme: Ortamda yalnızca Tess ile Joel'un bulunduğunu gören oyuncu için bu EM 'tutarsızlık hissi' ve 'akıl karışıklığı' yaratabilir. Bu örnekte çevirmenin, metnin geçtiği bağlama ilişkin yeterli bilgiye sahip olmadığı düşünülebilir. Kaynak metinde geçen "Be careful" ifadesine ait 'you' (sen) gizli öznesinin tekil veya çoğul kullanıldığı metin üzerinde belirsiz olduğu için, çevirmen bu kısmı "Dikkatli olun" şeklinde çevirmiş olabilir. Sınırlı bağlam bilgisi olduğu düşünülen bu örnekte çevirmenin tutarsızlığın önüne geçmek için her iki ihtimali de kapsayabilecek 'Dikkat.' ifadesini tercih etmesi önerilebilir. Oyun çevirisinde karşılaşılan sorunlardan biri, özellikle geliştirici firmanın dışarıdan çeviri hizmeti alması durumunda çeviri ekibine oyunun bağlamına ilişkin kısıtlı bilgi sağlamasıdır. Oyun şirketlerinin oyuna ait farklı metinleri (menü metinleri, senaryo metinleri, vs.) 
çevirmene tablo formatında oldukça kısıtlı bir bağlam bilgisi ile sunduğu durumlar bilinmektedir. ${ }^{22}$ Bu nedenle kimi zaman, çeviri metni yönlendiren dış bağlamın bilinmemesinden kaynaklanan çeviri hatalarıyla karşılaşılmaktadır. The Last of Us'ın Türkçe çevirisinde de zaman zaman bu durumun yaşandığı görülmektedir. Bu noktada kuramsal çerçevede vurgulandığı gibi takım çalışmasını anahtar bir öneme sahiptir.

\section{3. Örnek}

Bağlam bilgisi: Joel, Tess ile yolculuğuna devam eder. Yüksek bir duvara tırmanmak için Joel önce elleriyle Tess'in basıp yükselebileceği bir basamak oluşturur. Tess, duvara çıktıktan sonra elini uzatıp Joel'u yukarı çeker.

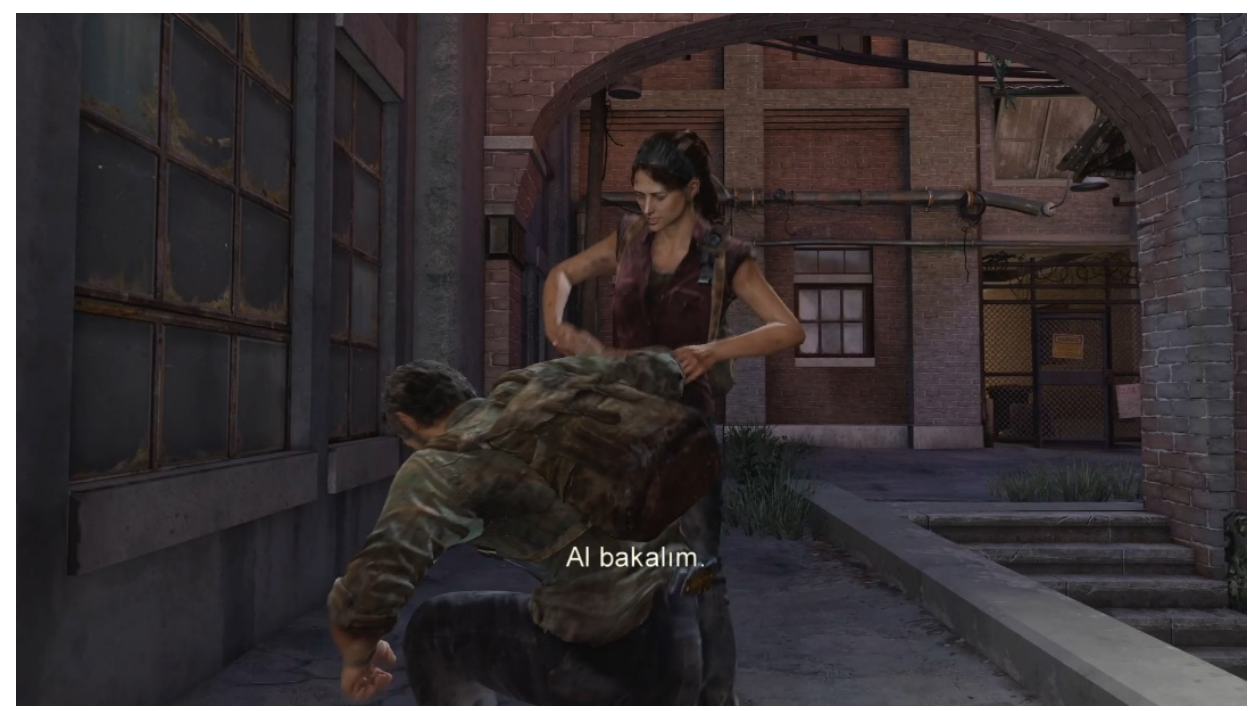

Resim 3

EM:

Tess: Al bakalım.

KM:

Tess: There you go.

Öneri:

Tess: Gel bakalım / İşte oldu / İşte böyle.

Değerlendirme: El uzatarak birini duvardan yukarı çektikten sonra "Al bakalım” karşılığı bir anlam ifade etmemektedir. Her ne kadar tırmanma sahnesinden hemen önce Tess'in söylediği "Give me your hand." ifadesi çevirmen için bir ipucu taşısa da cümlenin hangi şartlarda söylendiğini bilmeyen çevirmenin "There you go" ifadesini birincil anlamıyla (bir şey uzatırken/verirken/yaparken yardım edilen kişiye söylenen söz) kullandığı görülmektedir. Görüldüğü gibi, görsel-işitsel bir ürün olan oyunda sahne ve alt yazı çevirisinin

\footnotetext{
${ }^{22}$ Bu bilgi, araştırmacıların ilgili alandaki artalan bilgisi ve sektördeki çeviri deneyimlerinden yola çıkarak ifade edilmektedir.
} 
uyumlu olması önem taşır. Çeviri süreci normları düşünüldüğünde bu tip kalıp ifadelerin çevirmene bir bilgi notuyla sunulması sorunun önüne geçecektir. Örneğin "There you go." gibi ifadelerin farklı kullanım yerlerini bilen geliştirici firma, çevirmene bu ifadelerin hangi durumlarda kullanılacağı bilgisini verebilir (örneğin yüksek bir yere tırmanırken, bir nesne uzatırken, bir talebi yerine getirirken vb.).

\section{4. Örnek}

Bağlam bilgisi: Joel ve Tess'den kaçan Robert'ın karşısına demir bir kapı çıkar. Robert kapıyı zorlayarak açmaya çalışırken öfke, korku ve aceleyle tepki verir.

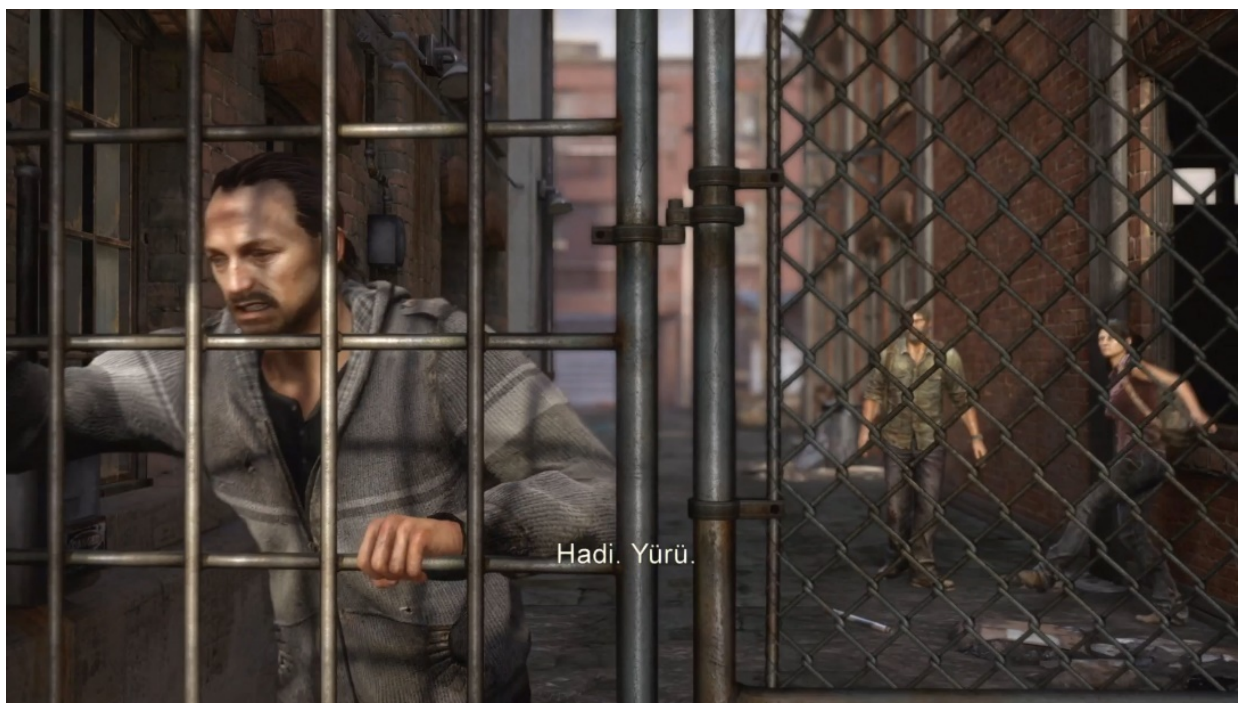

Resim 4

EM:

Robert: Hadi. Yürü.

KM:

Robert: Come on.

Öneri:

Robert: Hadi. / Hadi açılsana!

Değerlendirme: Robert’ın "Hadi. Yürü.” karşılığı sahneye uymamaktadır. Kapı, yürüme fiilinin kullanılacağı bir nesne olmadığı için erek kitle için yadırgatıcı olabilir. Ancak ikinci, üçüncü ve dördüncü örneklerde görülen sahne ve erek metin uyuşmazlıkları yalnızca çevirmen tercihleriyle açıklanamayabilir. Bazı durumlarda çevirmenden oyunun çeşitli yerlerinde kullanılacak belli başlı kalıp ifadelerin çevrilmesi talep edilebilmektedir. İngilizcede 'be careful, behind you, watch your step, come on, watch out' gibi ifadelerin kullanıldıkları sahne bilgisinin çevirmene bildirilmesi veya farklı durumlarda kullanmak üzere hem tekil hem çoğul özneyle çevirisinin talep edilmesi bu sorunun önüne geçebilir. Bu 
ifadeler her ne kadar İngilizcede ortak bir havuzdan kullanılabilir olsa da Türkçe gibi tekil ve çoğul kullanımın fiil çekimini etkilediği dillerde bu yöntem birebir uygulandığında işlevsel bir sonuç yaratmamaktadır. Öte yandan bu örnekte sahne görülmeden sadece metin üzerinden çevrilmek zorunda kalındığında iletişimi sağlamak için 'Hadi' karşılığı tercih edilerek anlamsal zemin oluşturulabilir ve sorun çözülebilir.

\section{5. Örnek}

Bağlam bilgisi: Joel ve Tess, karantina bölgesinden geçmektedir. Sokağın güvenli olup olmadığını öğrenmek için küçük bir çocuktan yemek karnesi karşılığında gözcülük yapmasını ister.
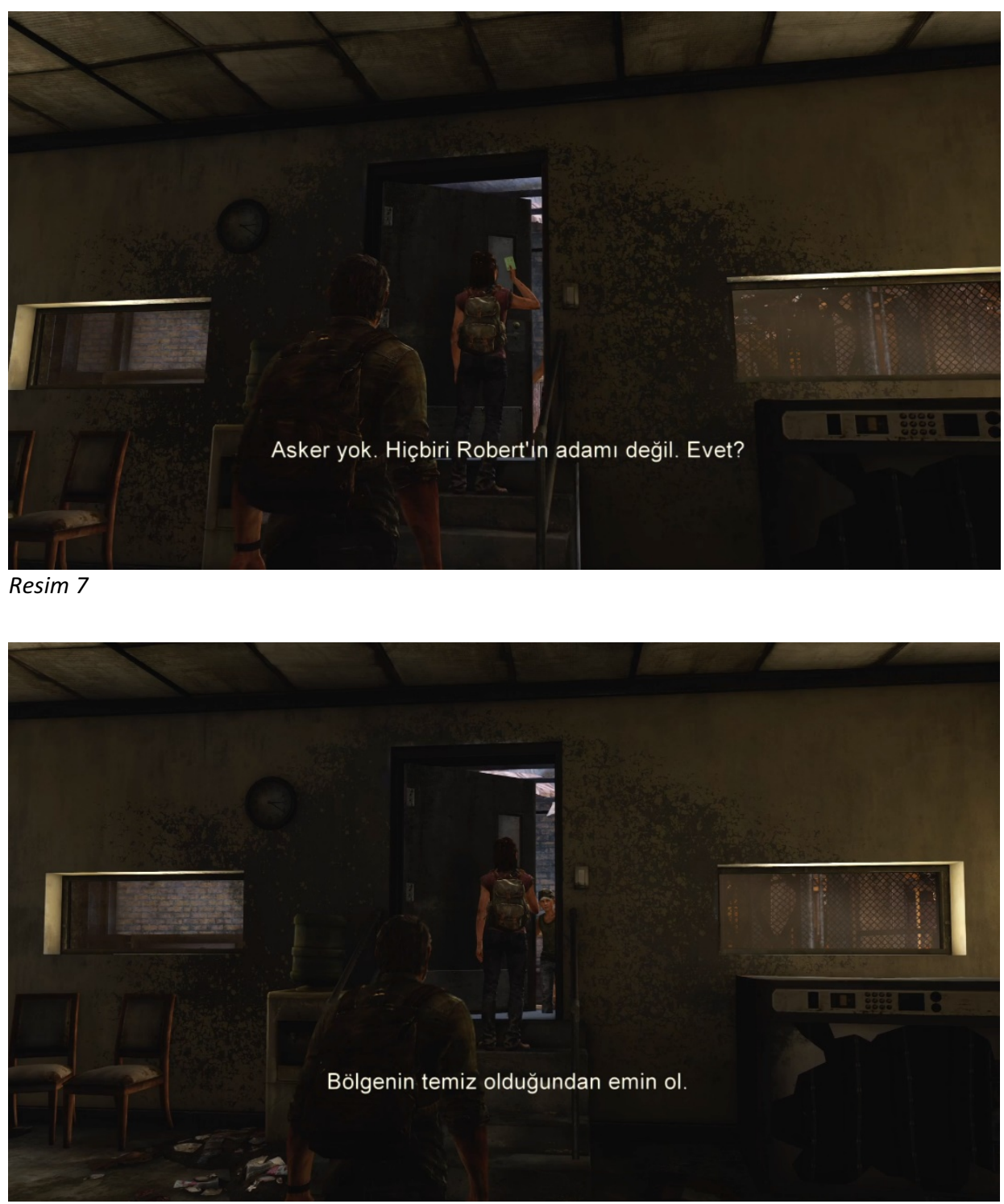
Resim 8

EM:

Tess: Bölgenin temiz olduğundan emin ol.

Asker yok. Hiçbiri Robert'ın adamı değil. Evet?

KM:

Tess: Make sure the coast is clear.

No soldiers. None of Robert's men. Yeah?

Öneri:

Tess: Etrafın temiz olduğundan emin ol.

Asker de, Robert'ın adamı da olmasın. Tamam?

Değerlendirme: “Asker yok. Hiçbiri Robert'ın adamı değil. Evet?” ifadesinin Türkçe dil kullanımıyla örtüşmeyen ve oyuncuyu yadırgatabilecek bir kullanım oluşturduğu düşünülebilir. Diyaloğun geçtiği sırada Tess çocuktan henüz bilgi almamış (çünkü çocuk hiçbir şey söylememektedir), ona yemek karnesi karşılığında bir görev vermiştir. Ancak erek metinde öne çıkartılan anlam, Tess'in hali hazırda konuyla ilgili bir bilgiye sahip olduğu fikrini uyandırmaktadır. Anlatıda kopukluğa sebep olan bu muğlaklık, oyunun sahnesinin doğru bir şekilde çözümlenemeyişinden kaynaklanmaktadır. Bunun sebebi, kaynak metne duyulan sadakat, metnin doğru çözümlenememesi veya herhangi bir bağlam bilgisinin sağlanmaması olabilir. Öte yandan Tess'in çocuktan temiz olduğundan emin olmasını istediği alan, sınırı çizilmiş bir bölge değil, o anın çabukluğuyla gözlenmesi mümkün olan yakın çevredir. Dolayısıyla 'etraf' tercihi gözetleme eyleminin aceleciliğini yansıtmak açısından daha işlevsel olabilir. Tüm bu değerlendirmeler ışığında "Asker de, Robert'ın adamı da olmasın. Tamam?" ifadesi oyundaki akışa uyan bir çözüm olabilir.

\section{6. Örnek}

Bağlam Bilgisi: Joel ve Tess karantina bölgesinde bir kontrol noktasından geçmek üzere askerlerin nöbet tuttuğu bariyerli kapıya yönelir. Ellerinde gerekli evraklar bulunmaktadır. Bu sayede sorunsuz bir şekilde kapıdan geçmeyi umarlar. O sırada geçmek istedikleri bölgede silahlı bir çatışma patlak verir ve askerler kontrol noktasından geçişi kapatarak çatışmaya müdahale eder. Artık Joel ve Tess'in gitmek istedikleri yere ulaşmak için daha uzun bir yolu aşması gerekmektedir. Hızlıca eski bir binaya yönelen ikili içeri girer. $\mathrm{O}$ anda Tess öfkesini belli eden bir cümle kurar. 


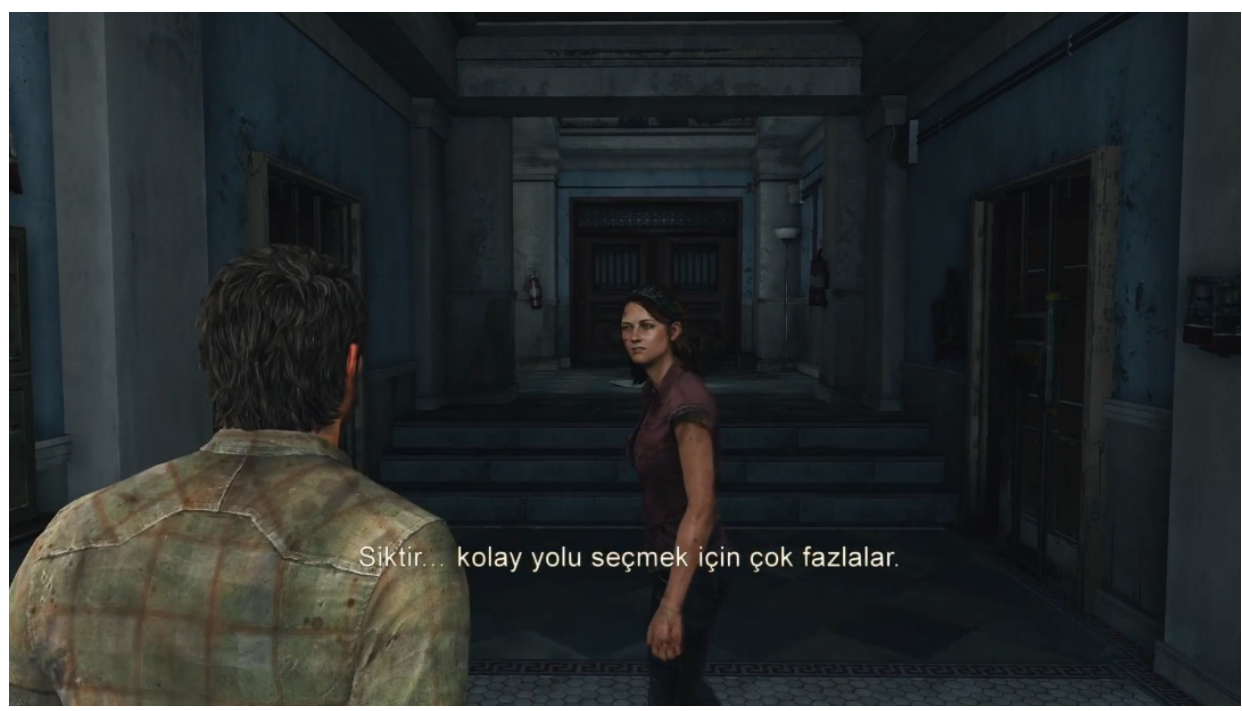

Resim 5

EM:

Tess: Siktir... kolay yolu seçmek için çok fazlalar.

KM:

Tess: Fuck... So much for the easy route.

\section{Öneri:}

Tess: Siktir... Bu kadar kolay gitseydik şaşardım!/Bu kadar kolay olsaydı şaşardım zaten!/Kestirme yol buraya kadarmış!

Değerlendirme: EM'deki çözümün oyuncuya herhangi bir anlam ifade etmeyeceği söylenebilir. Aksine bu çeviri oyuncuyu yanlış yönlendirebilecek bir anlam taşımaktadır. Ara sahnede çatışma seslerinin duyulmasının ardından oyunun temposunda bir artış görülmektedir ve "kolay yolu seçmek için çok fazlalar." cümlesi oyuncuda anlam karmaşasının yanında bir çatışmanın içine girildiği fikrini uyandırabilir. Hâlbuki ortada "kolay yolu seçecek' bir insan grubu olmadığı bilinmektedir. Karakterin söylemi, ancak KM’ne bakıldığında anlaşılabilir. İngilizcede bir durum beklenmeyen bir şekilde sonuçlandığında yaşanan hayal kırıklığını ifade etmek için kullanılan 'so much for' kalıbı bağlam içinde de benzer bir vurgu taşımaktadır (artık kapı kapanmıştır ve ikilinin yolu uzamıştır). Bir önceki ve bu örnekte görüldüğü gibi, kaynak metne kelime düzeyinde sadık kalındığında erek metin oyuncuda amaçlanan anlamı vermeyecektir. 


\section{7. Örnek}

Bağlam Bilgisi: Joel ve Tess bir odaya girer. İçeride Tess'in tanıdığı bir adamla karşılaşırlar. Adam Tess'e iyi haberler verir.

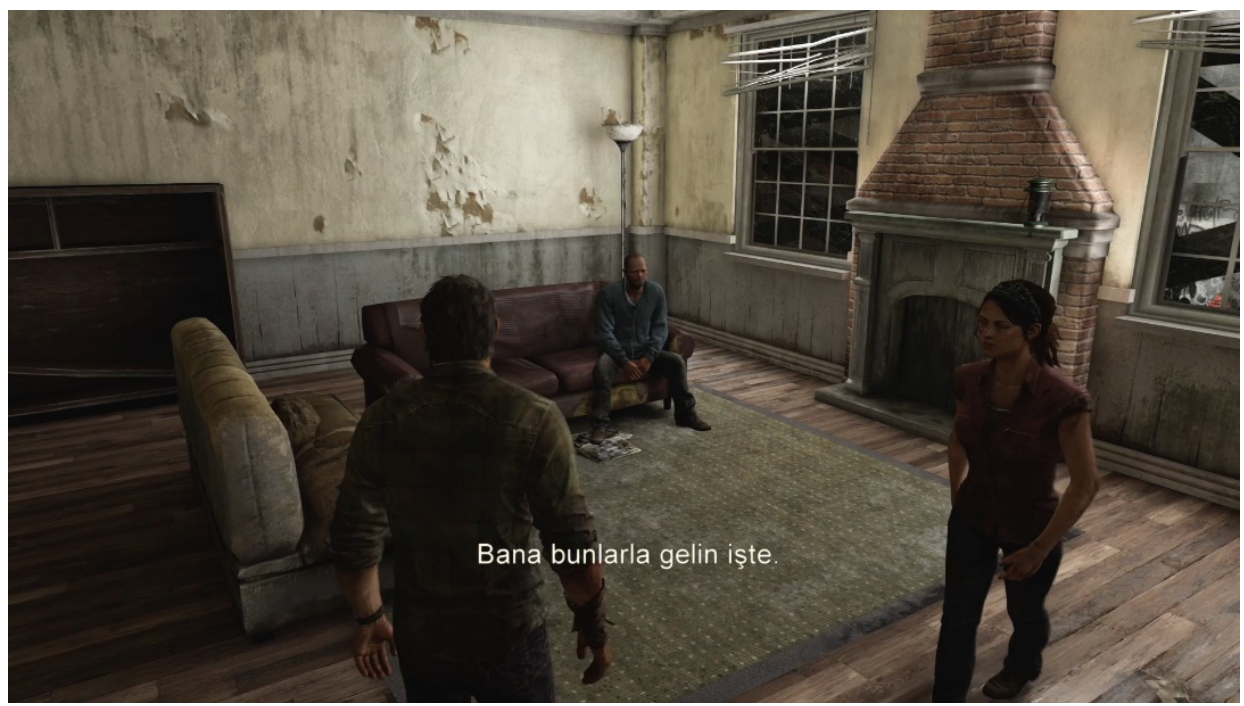

Resim 6

\section{EM:}

"Bana bunlarla gelin işte"

KM:

"That's what I like to hear"

Değerlendirme: Tess'in bu haberler karşısında verdiği tepkinin hem karakter söylemine hem de erek kültürün gündelik kullanımı çerçevesinde doğal akışa uygun olduğu görülebilir. Bu doğallığı sağlamakta erek metin odaklı bir çözüm sunulması büyük öneme sahiptir. İlgili ifade kaynak metne sadık kalarak "İşte duymak istediğim şeyler bunlar" olarak çevrilseydi de oyuncuyu yadırgatmayan bir çözüm oluşturulabilirdi ancak bu örnekteki gibi karakterin 'konuşturulması', duruma bir doğallık katmış ve karakterin gerçekliğine söylem yoluyla olumlu etki etmiştir. 


\section{8. Örnek}

Bağlam Bilgisi: Sarah gece yarısı çalan telefonla uyanır. Arayan amcasıdır ve Joel'un nerede olduğunu sormaktadır. Oyuncunun yönlendirdiği Sarah evde babasını ararken banyoda bir gazete görür. Ekranda bir gazetenin ilk sayfasındaki manşetler görünür.

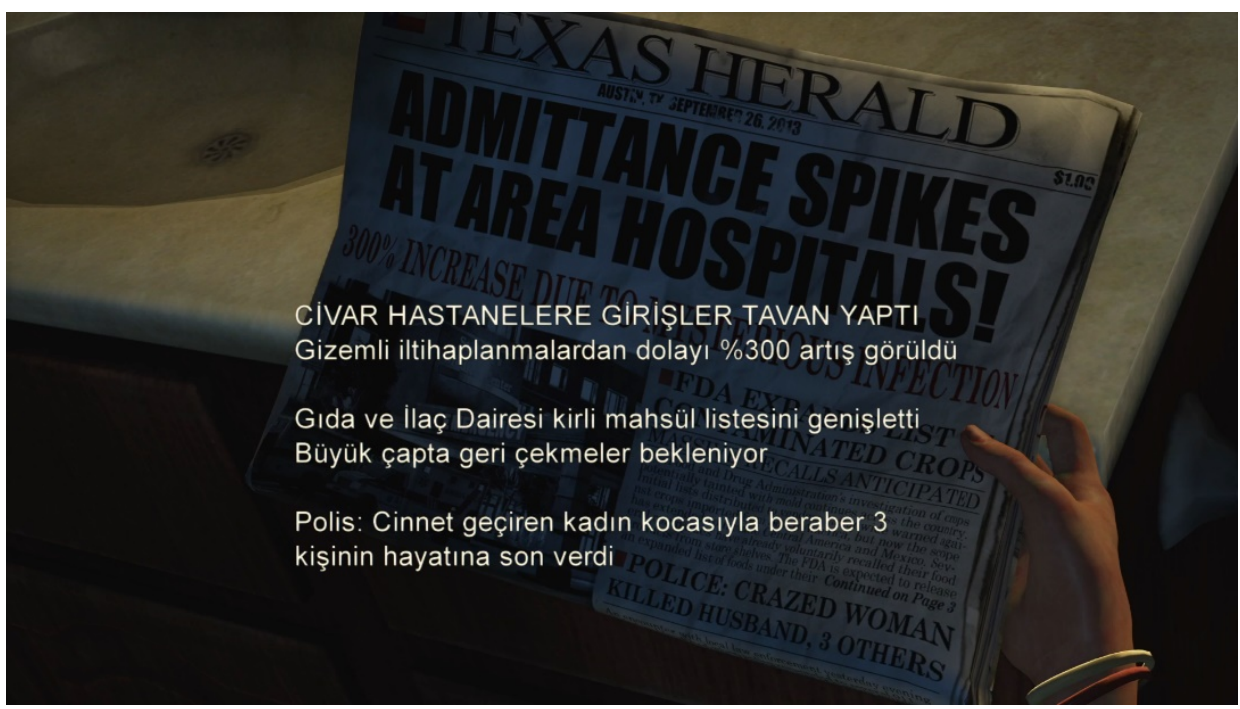

$\operatorname{Resim} 7$

EM:

Civar Hastanelere Girişler Tavan Yaptı - Gizemli İltihaplanmalardan Dolayı \%300 Artış Görüldü

Gıda Ve İlaç Dairesi Kirli Mahsül Listesini Genişletti - Büyük Çapta Geri Çekmeler Bekleniyor

KM:

Admittance Spikes At Area Hospitals! 300\% Increase Due To Mysterious Infection Fda Expands List Of Contaminated Crops - Massive Recalls Anticipated-

Öneri:

Bölgedeki hastanelere beklenmedik akın! Gizemli enfeksiyon nedeniyle hasta girişleri 4 kat arttı.

Gıda ve İlaç Dairesi Kirli Mahsul Listesini Genişletti- Birçok Mahsulün Piyasadan Çekilmesi Bekleniyor.

Değerlendirme: Bir gazete formatında sunulan bu metnin çevirmene bağlam bilgisiyle birlikte sağlanıp sağlanmadığı çeviri kararlarını etkilemektedir. Ancak çevirmenin metin edinciyle bunun bir haber metni olduğunu çözümleyebilmesi ve erek kültürün haber geleneğine uygun bir çeviri yapması oyuncuya da bir haber metni okuduğunu hissettirecektir. Bu örnekte, "Civar Hastanelere Girişler Tavan Yaptı" ve "Gizemli İltihaplanmalardan Dolayı" ifadeleri bu bağlamda yadırgatıcı olarak görülebilir. Bu aşamada, çözümlerin 
erek dil ve kültürün haber metinleri geleneğine uygunluğu değerlendirme ölçütü olarak görülebilir. Özellikle dil kullanımı, manşet ve sürmanşet bağlantısı gibi metin geleneğini oluşturan öğeler göz önünde bulundurulmalıdır. Bu çerçevede, Türkçe günlük haber metni dili düşünüldüğünde (ekonomi gibi istatistiki veriye dayanan bir haber değilse), EM'de yer alan '\%300 artış' ifadesi yerine, '4 kat arttı' ifadesinin daha uygun olduğu söylenebilir.

EM çözümlerinde yer alan 'Kirli mahsul' ifadesi ilk bakışta yadırgatıcı bir tercih olarak görülse de yapılan araştırma, alan geleneğinin bu yönde olduğuna işaret etmektedir. Bu noktadaki yadırgatıcılık hata olarak tanımlanmamalıdır. Öte yandan haberin devamında "Büyük Çapta Geri Çekmeler Bekleniyor." ifadesinin bir önceki cümleyi destekler nitelikte olması gerekir. Ancak burada geri çekilenin ne olduğu (ilaç, gıda, asker, personel vb.) muğlak bırakılmıştır. "Birçok Mahsulün Piyasadan Çekilmesi Bekleniyor." çözümü ile mahsul kelimesinin tekrar edilmesi, geri çekilenin kirli mahsuller olduğu bilgisini açıkça sağlamaktadır. Örneğin devamında FDA gibi birimlerin karşılıkları için tam yerelleştirmenin gerekip gerekmediği bilgisi belirleyici olabilir. Bu noktada, süreç öncesinde alınan kararlar doğrultusunda kurum ve kuruluşların da muadil birimlerle erek kültürdeki karşılıklarıyla kullanılması ya da yeni karşııık bulunması yoluna gidilebilir. Ancak böyle bir beklenti yoksa FDA muğlak bir şekilde gıda ve ilaç dairesi olarak bırakılabilir. Sonuç olarak FDA ile aynı işlevi gören bir birimin bir liste yayımladığı bilgisi karşılandığı zaman işlevsellik sağlanacaktır.

\section{Sonuç Bulguları ve Değerlendirme}

Karmaşık, kültür bağımlı, sanatsal ürünler olan oyunlar, kimi zaman oyuncuya bir hikâye anlatır. Bu durumda çevirmen de iyi bir hikâye anlatıcısı olmalıdır. Çalışmada görüldüğü gibi, anlatılan bu hikâye oyunun erek kültürdeki temsiline önemli bir katkı sağlamaktadır.

Yukarıda sözü edilen katkının görünür kılınması için özellikle kazandığı hikâye ödülleri ile ön plana çıkan bir oyun bütünce olarak seçilmiştir. Bütüncenin değerlendirilmesi için ilk olarak oyun çevirisini kuşattığı düşünülen iç ve dış bağlam ele alınmıştır. Bu çerçevede, oyunlarda görsel-işitsel öğeler bulunması ve erek dilde yazılı/sözlü dil desteğine ihtiyaç duyulması nedeniyle görsel-işitsel çeviri ile bağlantılı ele alınabileceği düşünülmüştür. Öte yandan, oyun çevirisinin kendine ait normlarını gözlemleyebilmek için betimleyici bir yaklaşımla hareket edilmiştir. Bu yaklaşım, örneklerin değerlendirilme yöntemine de ışık tutmuştur. Çalışma amacına koşut çevirinin anlam dünyasını oluşturmadaki rolünü sekteye uğratabileceği düşünülen örnekler değerlendirilmiştir. Bu noktada, Toury'nin "sorun-çözüm çifti” yaklaşımından hareketle, erek kültürü yadırgatıcı unsurların kaynak metinde nasıl yer aldığı çerçevesinde bir karşılaştırma yapılmıştır. Bu kapsamda önemli görülen noktalar ve ulaşılan sonuçlar aşağıdaki şekilde özetlenebilir:

- Hikâyeyi oluşturan görsel ve işitsel öğelerin tamamlayıcısı olan metinler ancak amaca yönelik çeviri kararlarının alınması ile erek kültürde anlam kazanabilir. Böylece, hikâye odaklı oyunun çevirisi, hikâyeyi aynı zenginlikte yansıtırsa oyunun geliştirilme amaçlarından en önemlilerinden biri karşılanmış olacaktır. 
- Bu çalışmanın vurgusu, oyuncuyla duygu paylaşımını hedefleyen hikâye odaklı oyunlarda çevirinin bu yaratıcı aktarımdaki rolünün ne kadar önemli olduğuna işaret etmektir. Bu nedenle çalışmada incelenmek üzere seçilmiş örnekler, oyunun oynanabilirliğini doğrudan etkileyen ve oyuncuyu yönlendiren metinler değil, oyunun vadettiği kaliteli hikâye anlatımını oluşturan metinsel öğelerdir. Bu öğelerin önemine dikkat çekmek için çalışmada, anlam dünyasının sürece veya çevirmene bağlı etkenlerden dolayı sekteye uğradığı düşünülen örnekler seçilmiştir. Oyunun bütününe bakıldığında, Türkçe çevirinin oyunun oynanabilirliğine ve anlam dünyasının oluşturulmasına uygun çeviri tercihleriyle şekillendirildiği söylenebilir.

- $\quad$ Erek metindeki yadırgatıcı unsurların çeviri sürecinden ve/veya aktör olarak çevirmenden kaynaklanabildiği görülmüştür. Sürece ilişkin bazı teknik düzenlemelerin yapılması daha kaliteli bir çeviri ürünü ortaya koyacaktır. Bu doğrultuda çeviri için ayrılan sürenin düzenlenmesi, gerekli çeviri araçlarının sunulması, bağlam bilgisinin sağlanması, oyunun test sürümüne çevirmenin dâhil olması ve böylelikle dil verisi ile oyundaki sahnelerin aynı anda değerlendirilebilmesi önem taşımaktadır. Çevirmen aktarım çerçevesinde bir iletişim uzmanı olduğundan, değerlendirme sürecinde de aldığı kararları gerekçelendirebileceği ortamın sağlanması, doğru bir dil tercihi bile olsa, teknik kısıtılıklar nedeniyle değiştirilmesi gereken tercihlerin yine uzman bir iletişimci çevirmen tarafından önerilmesi bu süreci daha sağlıklı kılabilir. Bu süreçte özellikle çevirmenlerin uzman konumunda kontrol sürecine dâhil edilmesi ya da gerekli bilgileri talep etmeleri önem taşımaktadır. Daha geniş bağlamda, kaliteli bir ürünün ortaya çıkması için çevirmen dışındaki aktörlerin de desteğine ihtiyaç duyulduğu görülmektedir.

- Çevirmen boyutunda düşünüldüğünde çeviri edincinin önemi ortaya çıkmaktadır. İlk olarak metin türüne özgü normların çeviri kararlarına yansıtılması gerektiği görülmüştür. Bunun için, çevirmenin çeviri amaçlı metin çözümlemesi ve sürece ilişkin araştırma yapabilmesi önemlidir.

- Öte yandan, çeviride yaratıcılık kavramının tanımı da genişleyerek sadece geleneksel yazınsal türlerde değil, dijital ürünler olarak nitelendirilen oyunlardaki önemi giderek görünür olmaktadır.

- Bu noktada, özel alanlara yönelik çeviri edincinin kazandırılması çeviri eğitimi ile bağlantılı ele alınabilir. "iletişim uzmanı" yetiştirmek üzere çeviri edinci kazandırmayı hedefleyen çeviri eğitiminin bu noktadaki önemi ortaya çıkmaktadır. Bu nedenle çeviribilim programlarının müfredatlarına eklenmekte olan yerelleştirme, dijital oyun çevirisi, çeviri teknolojileri, altyazı çevirisi konulu derslerin yaygınlaşması oyun çevirisi alanında nitelikli çevirmenlerin yetiştirilmesi için önemli bir başlangıç noktası oluşturmaktadır.

Tüm bu maddelerden görüldüğü gibi, bu çalışmanın bütüncesini oluşturan oyun çevirisi sürecinde aktörlerin süreci etkileyen öneme sahip olduğu, bu nedenle çeviri kararlarının değerlendirilirken metin içi ve metin dışı süreci etkileyen farklı unsurların da 
göz önünde bulundurulması gerekliliği, çevirmenlerin ele aldığı metinlerin gerçek bir iletişim ortamını yansıtmasının hedeflendiği görülmektedir. Bu durum, eğitim ve uygulama arasındaki iş birliğinin ve ortak bir noktada buluşabilme gerekliliğinin altını bir kez daha çizmektedir.

\section{Kaynakça}

Ankara Kalkınma Ajansı. (2016, Aralık 1). Dijital Oyun Sektörü Raporu. Ağustos 5, 2018 tarihinde Ankara Kalkınma Ajansı: http://www.ankaraka.org.tr/tr/dijital-oyun-sektoru-raporu_3414.html adresinden alındı

(t.y.)., P. S. (tarih yok). The Last of Us Remastered. Şubat 19, 2019 tarihinde PLAYSTATION STORE: https://store.playstation.com/tr-tr/product/EP9000-CUSA00556_00-THELASTOFUS00000/ adresinden alındı

Akbulut, H. (2009). Dijital Oyun Rehberi. (M. Binark, G. Bayraktutan Sütcü, \& I. Fidaner, Dü) İstanbul: Kalkedon Yayınları.

Alkan, S. C. (2013). Web Sitesi Yerelleştirmelerinde Bir Eyleyen Olarak Çevirmenin Konumu: Türkiye Örneği. ìstanbul: İstanbul Üniversitesi Sosyal Bilimler Enstitüsü.

Aydemir, O. (2016, Aralık 11). Türkiye Oyun Sektörü 2016 Raporu ve Gaming in Turkey. Ağustos 5, 2018 tarihinde SlideShare: https://www.slideshare.net/ozanamrasaydemir/trkiye-oyun-sektr-2016raporu-ve-gaming-in-turkey adresinden alındı

Bengi-Öner, I. (1999). [Öz-]Sorgulamalar: Hata Avcılığı 1: Yazın Çevirisiyle Neden Uğraşmalı? Nasıı Uğraşmalı? I. Bengi-Öner içinde, Çeviri bir Süreçtir... Ya Çeviribilim? (s. 137-148). İstanbul: Sel Yayıncılık.

Bengi-Öner, I. (1999). [Öz-]Sorgulamalar: Hata Avcılı̆̆ 2: Çevirmen, Eleştirmen, Kuramcı Üçgeninde Hata Nerede? I. B. Öner içinde, Çeviri bir Süreçtir... Ya Çeviribilim? (s. 149-154). İstanbul: Sel Yayıncılık.

Bengi-Öner, I. (2006, Haziran). "Yerelleştirme"nin Tanımı. Varlık Yayınları, s. 33-35.

Berk, Ö. (2005). Kuramlar Işığında Açıklamalı Çeviribilim Terimcisi. İstanbul: Multilingual.

Bernal-Merino, M. (2008). What's in a Game. Localisation Focus, 6(1), s. 29-38.

Bernal-Merino, M. (2015). Translation and Localisation in Video Games: Making Entertainment Software Global. New York: Routledge.

BNL History: The First Video Game? . (tarih yok). Şubat 26, 2019 tarihinde https://www.bnl.gov/about/history/firstvideo.php adresinden alındı

Brown, A., \& Bidarra, R. (2017). Introduction. DiGRA Journal, 2(3). Mart 18, 2018 tarihinde http://todigra.org/index.php/todigra/article/view/66/114 adresinden alındı

Çelik, M. (2009, Ağustos 8). Oyunlarda Çeviri ve Yerelleştirme: Türkiye'den bir Örnek. (I. B. Fidaner, Röportaj Yapan) Temmuz 2, 2018 tarihinde https://yersizseyler.wordpress.com/2009/08/08/oyunlardaceviri-ve-yerellestirme-turkiyeden-bir-ornek/ adresinden alındı

Díaz-Cintas, J. (2008). Audiovisual Translation Comes of Age. D. Chiaro, C. Heiss, \& C. Bucaria içinde, Between Text and Image: Updating research in screen translation (s. 1-11). Amsterdam: John Benjamins Publishing.

Dog, N. [Naughty_Dog] (2018, Haziran 14). Today is the 5th Anniversary of The Last of Us' release. Over 17 million of you have taken this journey with us and your love, support, and fandom for these characters and their story has been incredible. We can't wait to continue it with Part II.pic.twitter.com/dES9bBDa4W [Tweet]. https://twitter.com/Naughty_Dog/status/1007320235731488770 adresinden alındı. 
Fidaner, I. B. (2009, Ağustos 8). Oyunlarda Çeviri ve Yerelleştirme: Türkiye'den Bir Örnek. Nisan 2, 2018 tarihinde Yersiz Şeyler: https://yersizseyler.wordpress.com/2009/08/08/oyunlarda-ceviri-veyerellestirme-turkiyeden-bir-ornek/ adresinden alındı

Frasca, G. (2001). Rethinking Agency and Immersion: videogames as a means of consciousness-raising. Digital Creativity, 12(3), 167-174. Mart 2, 2018 tarihinde https://www.tandfonline.com/doi/pdf/10.1076/digc.12.3.167.3225?needAccess=true adresinden alındı

Fung, J. (2012). Best Practices for Game Localization. taslak. Mayıs 13, 2018 tarihinde https://c.ymcdn.com/sites/www.igda.org/resource/collection/2DA60D94-0F74-46B1-A9E2F2CE8B72EA4D/Best-Practices-for-Game-Localization-v22.pdf adresinden alındı

Gambier, Y., \& Gottlieb, H. (2001). (Multi) Media Translation. Amsterdam: John Benjamins Publishing.

Gaming in Turkey. (2018, Haziran 22). Turkey Game Market 2017 Report - Gaming in Turkey - Gaming \& Esports. Ağustos 5, 2018 tarihinde SlideShare: https://www.slideshare.net/GaminginTurkey/turkey-game-market-2017-report-gaming-inturkey/ adresinden alındı

Gaming in Turkey Oyun Ajansı. (tarih yok). Oyun Lokalizasyon Yerelleştirme Servisleri. Ocak 4, 2019 tarihinde Gaming in Turkey: https://www.gaminginturkey.com/tr/oyun-lokalizasyon-ve-yerellestirmegaming-in-turkey/ adresinden alındı

Gouadec, D. (2007). Translation as a Profession (Cilt 73). Amsterdam/Philadelphia: John Benjamins Publishing Company.

HABERTURK. (2019, Ocak 18). 2018 oyun yazılımı ihracat rakamları açıklandı. Şubat 18, 2019 tarihinde HABERTURK: https://www.haberturk.com/yerli-oyun-ihracati-1-milyar-dolari-gecti-2295898teknoloji adresinden alındı

IMDb. (tarih yok). The Last of Us - Awards. Ağustos 18, 2018 tarihinde IMDb: https://www.imdb.com/title/tt2140553/awards adresinden alındı

İnce, Ü. (1997). Kuram ve Uygulama Bilgisiyle Çeviri Eleştirisi. H. Anamur (Dü.) içinde, Hommage a Hasan-Âli Yücel Çeviri, Ekinler ve Zamanlar Kavşağı (s. 253-259). İstanbul: İstanbul Yıldız Teknik Üniversitesi.

Kılıç, E. (2018, Mayıs 8). Türkiye Yerli Oyunlardan 700 Milyon Dolar Kazandı! Ağustos 4, 2018 tarihinde TOGED: http://www.toged.org/turkiye-yerli-oyunlardan-700-milyon-dolar-kazandi/ adresinden alındı

Mangiron, C., \& O'Hagan, M. (Temmuz 2006). Game Localisation: Unleashing Imagination with 'Restricted' Translation. The Journal of Specialised Translation, 10-21.

MIT. (tarih yok). Spacewar! Şubat 4, 2019 tarihinde The MIT 150 Exhibition: http://museum.mit.edu/150/25 adresinden alındı

Munday, J. (2008). Introducing Translation Studies: Theories and Applications (2 b.). New York: Routledge.

O'Hagan, M., \& Mangiron, C. (2013). Game Localization: Translation for the global digital entertainment industry. Amsterdam: John Benjamins Publishing.

Okyayuz, A. Ş., \& Kaya, M. (2017). Görsel-Işitsel Çeviri Eğitimi. Ankara: Siyasal Kitabevi.

PlayStation. (tarih yok). The Last of UsTM Remastered. Şubat 22, 2019 tarihinde PlayStation: https://www.playstation.com/en-us/games/the-last-of-us-remastered-ps4/ adresinden alındı

Pym, A. (2014). Localization, training and instrumentalization. s. 37-50. Haziran 11, 2018 tarihinde http://www.intercultural.urv.cat/media/upload/domain_317/arxius/TP5/03-Pym.pdf adresinden alındı

Remael, A., \& Díaz-Cintas, J. (2014). Audiovisual Translation: Subtitling. New York: Routledge.

Saldanha, G., \& O'Brien, S. (2014). Research Methodologies in Translation Studies. New York: Routledge. 
Terek Ünal, G., \& Batu, U. (2011). Dijital Oyunlar: Kendi Dünyanda Yaşa Bizimkinde Oyna. (G. Terek Ünal, \& U. Batu, Dü) İstanbul: Derin Yayınları.

Tezel, Y. (2016). Bilgisayar Oyunları Tarihi. İstanbul: Sokak Kitapları Yayıncılık.

The Fun of Gaming. (tarih yok). Mart 1, 2019 tarihinde FUGA: http://fuga.aalto.fi/ adresinden alındı

Tishin, D. (2014, Haziran). A quest for quality in video game localization. Industry Focus, 35-39. Haziran 5, 2018 tarihinde http://dig.multilingual.com/2014-06/index.html?page=35 adresinden alındı

Toury, G. (1995). Descriptive Translation Studies and Beyond. Amsterdam: John Benjamins.

Toury, G. (2012). Descriptive Translation Studies and Beyond. Amsterdam: John Benjamins Publishing Company.

Trosborg, A. (1997). Translating Hybrid Political Texts. A. Trosborg (Dü.) içinde, Text Typology and Translation (Cilt 26, s. 145-158). Amsterdam: John Benjamins Publishing Co.

Wijman, T. (2018, Nisan 30). Mobile Revenues Account for More Than 50\% of the Global Games Market as It Reaches \$137.9 Billion in 2018. Temmuz 8, 2018 tarihinde https://newzoo.com/insights/articles/global-games-market-reaches-137-9-billion-in-2018mobile-games-take-half/ adresinden alındı

Wijman, T. (2018, Nisan 30). Mobile Revenues Account for More Than 50\% of the Global Games Market as It Reaches \$137.9 Billion in 2018. Mart 14, 2019 tarihinde NEWZOO: https://newzoo.com/insights/articles/global-games-market-reaches-137-9-billion-in-2018mobile-games-take-half/ adresinden alındı

Yazıcı, M. (2007). Yazılı Çeviri Edinci. İstanbul: Multilingual. 